\title{
Priocharax nanus, a new miniature characid from the rio Negro, Amazon basin (Ostariophysi: Characiformes), with an updated list of miniature Neotropical freshwater fishes
}

\author{
Mônica Toledo-Piza르, George M. T. Mattox ${ }^{2}$ and Ralf Britz ${ }^{3}$
}

Priocharax nanus, new species, is described from the rio Negro, Brazil. It is a miniature fish that retains as an adult the larval rayless pectoral fin, a diagnostic character of the genus. Priocharax nanus possesses fewer reductive features compared to congeners, $P$. ariel and $P$. pygmaeus, from which it can be distinguished by the presence of i,6 pelvic-fin rays (vs. i,5), the presence of the claustrum (vs. claustrum absent) and the presence of two postcleithra (vs. postcleithra absent). An updated list of 213 species of miniature Neotropical freshwater fishes is presented. The greatest diversity among them is represented by the Characiformes with 87 miniature species.

Priocharax nanus, espécie nova, é descrita do rio Negro, Brasil. É um peixe miniatura que retém no adulto a forma larval da nadadeira peitoral, um caráter diagnóstico do gênero. Priocharax nanus possui um número menor de caracteres redutivos quando comparado aos congêneres, $P$. ariel and $P$. pygmaeus, dos quais pode ser distinguida pela presença de i,6 raios na nadadeira pélvica (vs. i,5), presença do claustrum (vs. claustrum ausente) e presença de dois pós-cleitros (vs. pós-cleitros ausentes). Uma lista atualizada de 213 espécies de peixes miniatura de água doce neotropicais é apresentada. A maior diversidade entre eles é representada pelos Characiformes, com 87 espécies miniatura.

Key words: Heterocharacinae, Miniaturization, Reductive characters.

\section{Introduction}

Priocharax Weitzman \& Vari is a characid genus that includes two miniature species from the Amazon and Orinoco basins: P. ariel Weitzman \& Vari from the upper reaches of the ríos Orinoco and Negro in Venezuela, whose maximum length is $17.1 \mathrm{~mm}$ standard length (SL), and P. pygmaeus Weitzman \& Vari from the upper río Amazonas in Leticia, Colombia reaching $16.4 \mathrm{~mm}$ SL (Weitzman \& Vari, 1987). More recently, Priocharax ariel was also recorded in the region of Santa Isabel do Rio Negro, rio Negro basin (Lima \& Toledo-Piza, 2001) and P. pygmaeus was collected from a small tributary of rio Solimões, in Amazonas, Brazil (Oliveira et al., 2009).

Weitzman \& Vari (1987) listed six diagnostic characters for Priocharax, the most conspicuous of which is the presence of a rayless pectoral fin fold in the adult, which is otherwise restricted to larval stages of characiforms and teleosts in general. Priocharax species also have the upper and lower jaws with a high number of tiny conical teeth, the adults are diminutive in size being among the smallest characiforms known, specimens have 16-22 branched anal-fin rays and only five branched pelvic-fin rays. In addition to the two species of Priocharax, the only other Characidae known to us that consistently has i,5 pelvic-fin rays is Cyanogaster noctivaga Mattox, Britz, Toledo-Piza \& Marinho, another miniature characid from the rio Negro (Mattox et al., 2013).

One year after describing the diminutive Priocharax, Weitzman \& Vari (1988) provided a comprehensive review on miniaturization of South American freshwater fishes including a list of 85 species that either matured under $20 \mathrm{~mm}$ SL or did not exceed a maximum of $26 \mathrm{~mm} \mathrm{SL}$. The authors included 49 species of Characiformes in that original list,

${ }^{1}$ Departamento de Zoologia, Instituto de Biociências, Universidade de São Paulo. Rua do Matão, Travessa 14, nº 101, 05508-090 São Paulo, SP, Brazil.mtpiza@usp.br

${ }^{2}$ Departamento de Biologia, Universidade Federal de São Carlos - câmpus Sorocaba. Rodovia João Leme dos Santos (SP-264), km 110, Bairro do Itinga, 18052-780 Sorocaba, SP, Brazil. gmattox@ufscar.br

${ }^{3}$ Department of Zoology, The Natural History Museum, Cromwell Road, SW7 5BD, London, United Kingdom. r.britz@nhm.ac.uk 
nearly $60 \%$ of the total number of miniature species in South American freshwaters. Of their 49 miniature Characiformes, 46 were classified in the Characidae (including eight species of characidiines now considered to belong to the Crenuchidae) and three in the Lebiasinidae. Over a decade later, Costa \& Le Bail (1999) added 24 Neotropical freshwater fish species to that list including four characiforms, seven siluriforms and 13 cyprinodontiforms. Since then, a great number of miniature Neotropical freshwater fishes have been discovered (e.g., Moreira, 2005; Schaefer et al., 2005; Caires \& Figueiredo, 2011; Dutra et al., 2012; Román-Valencia et al., 2012; Netto-Ferreira et al., 2013a), quite a number of which were placed into new monotypic genera (e.g., Géry \& Romer, 1997; Bührnheim et al., 2008; Zarske, 2010; Ribeiro et al., 2012; Netto-Ferreira et al., 2013b; Mattox et al., 2013). Since Weitzman \& Vari's (1988) and Costa \& Le Bail's (1999) lists, the Check List of Freshwater Fishes of South and Central America has been published (Reis et al., 2003), which helped to organize knowledge on Neotropical species and highlighted many miniature forms (sensu Weitzman \& Vari, 1988) not included in previous lists.

During a recent expedition to Santa Isabel do Rio Negro, a small town on the left bank of the rio Negro, State of Amazonas, we collected a number of specimens clearly assignable to the genus Priocharax, based among other features on the remarkable larval pectoral-fin. However, their characters did not fully match those of the two known species. A detailed study of their external and skeletal anatomy revealed that they represent a new species of Priocharax which we describe herein. We also use this opportunity of the discovery of another miniature characiform to provide an updated list of miniature Neotropical freshwater fish species.

\section{Material and Methods}

Counts and measurements follow Fink \& Weitzman (1974) and were taken on the left side of each specimen whenever possible. All measurements other than standard length (SL) are expressed as percentages of SL, except for subunits of the head which are expressed as percentages of head length (HL). Measurements were taken point to point with a precision of $0.1 \mathrm{~mm}$ from digital photographs of specimens taken under the stereomicroscope. Counts of vertebrae, teeth, and gill-rakers were obtained from 11 specimens cleared and double stained for cartilage and bone following the protocol of Taylor \& Van Dyke (1985). Total vertebral number includes the four vertebrae of the Weberian apparatus. The compound ural centrum was counted as a single vertebra. The gill-raker at the junction of the ceratobranchial and epibranchial is considered as the posteriormost gill raker on the lower branch of the gill arch. Photographs were made with a Zeiss Discovery V20 stereomicroscope with a Zeiss Axiocam digital camera attached. Osteological terminology follows Weitzman (1962) except for inner arm of the os suspensorium instead of os suspensorium, and outer arm of the os suspensorium instead of rib of fourth vertebra, following Conway \& Britz (2007). In the description, the frequency of each count is provided in parentheses after the respective count, with the count of the holotype indicated by an asterisk. Information on meristic and morphometric data of $P$. ariel and $P$. pygmaeus were taken from Weitzman \& Vari (1987). Specimens examined for this study are deposited in the Museu de Zoologia da Universidade de São Paulo (MZUSP), Instituto Nacional de Pesquisas da Amazônia (INPA) and the National Museum of Natural History, Smithsonian Institution (USNM).

In our updated list of miniature Neotropical freshwater fishes (Appendix I) we adopted the cut-off point of $26 \mathrm{~mm}$ SL for miniatures, used by Weitzman \& Vari (1988). We agree with them that although this number is arbitrary, it may serve as a preliminary guide to the study of miniature fishes. We included in the list all miniature species described after the last update made by Costa \& Le Bail (1999). We also checked the recent literature in search for updated records of maximum lengths of species included in the lists of Weitzman \& Vari (1988) and Costa \& Le Bail (1999). If the maximum length of a species was reported to exceed $26 \mathrm{~mm} \mathrm{SL}$, it was excluded from our list. If the recorded length was still under $26 \mathrm{~mm} \mathrm{SL}$, but larger than the record presented by previous authors, we included the new recorded length and cited the source of the information. A few nominal species in the previous lists have been recently synonymized. In those cases we included only the valid species name with its respective recorded maximum length. For ease of comparison we listed separately all species that were removed from the lists of Weitzman \& Vari (1988) and Costa \& Le Bail (1999) (Appendix II). We also updated many species names to reflect current classification. Much of the information used in our list was taken from Reis et al. (2003) which had the benefit to include in a single volume information previously scattered throughout the ichthyological literature, when the previous lists were compiled. Because the checklist of Reis et al. (2003) included freshwater fishes from the entire Neotropical region, we were also able to gather information on miniature freshwater fishes from drainages outside South America, so that our list encompasses a broader geographical area than that covered by the list of Weitzman \& Vari (1988) which was restricted to South America. The list of Reis et al. (2003) also revealed additional apparently miniature species from South American drainages that were not previously listed by Weitzman \& Vari (1988) or Costa \& Le Bail (1999). We have chosen to include in our list all species that are recorded in Reis et al. (2003) as not reaching beyond $26 \mathrm{~mm} \mathrm{SL}$, so that the information would be more easily available. 


\section{Priocharax nanus, new species}

Figs. 1-4

Holotype. MZUSP 114014, 13.8 mm SL, Brazil, Amazonas, Santa Isabel do Rio Negro, rio Negro basin, lake at right bank of rio Urubaxi, near igarapé Tapage, 0³3'44.2"S 6449'40.8”W, 26 Oct 2011, M. Toledo-Piza, G. Mattox, M. Marinho \& R. Britz.

Paratypes. MZUSP 114015, 9, 12.1-15.3 mm SL (3 c\&s, 14.1-15.3 $\mathrm{mm}$ SL), same data as holotype. MZUSP 114016, 5, 12.6-14.6 mm SL (2 c\&s, 13.4-13.8 mm SL), Brazil, Amazonas, Santa Isabel do Rio Negro, rio Negro basin, igarapé Tapage at left bank of rio Urubaxi, 0³0'5.3'S 6449'11.7'W, 26 Oct 2011, M. Toledo-Piza, G. Mattox, M. Marinho \& R. Britz. MZUSP 114017, 3, 13.5-14.6 mm SL (1 c\&s, 14.6 mm SL), Brazil, Amazonas, Santa Isabel do Rio Negro, rio Negro basin, first tributary of rio Negro above rio Daraá, 0²7'24.2”S 6446'54.1'W, 27 Oct 2011, M. Toledo-Piza, G. Mattox, M. Marinho
\& R. Britz. INPA 39891, 4, 12.5-13.9 mm SL; MZUSP 114018, 11, 11.1-15.4 mm SL (5 c\&s, 12.0-14.0 mm SL); USNM 427007, 4, 12.1-13.3 mm SL; Brazil, Amazonas, Santa Isabel do Rio Negro, rio Negro basin, rio Negro and tributaries near Santa Isabel do Rio Negro, 23-30 Oct 2011, M. Toledo-Piza, G. Mattox, M. Marinho \& R. Britz.

Diagnosis. Priocharax nanus is distinguished from $P$. ariel and $P$. pygmaeus by the presence of i,6 pelvic-fin rays ( $v S$. $\mathrm{i}, 5)$, the presence of the claustrum (vs. claustrum absent) and the presence of two postcleithra (versus postcleithra absent). Priocharax nanus can be further distinguished from $P$. ariel by the lower number of gill rakers on the lower limb of the first branchial arch (9-10, $n=11$ vs. 11-13) and by the relatively shorter caudal peduncle (13.5-16.8 \% SL vs. 18.1$23.7 \% \mathrm{SL}$ ). Although there is some overlap between the species, Priocharax nanus has a higher number of branched anal-fin rays compared to $P$. ariel $(21-26$, mean $=22.5, \mathrm{n}=$ 36 vs. $16-21$, mean $=18.5, \mathrm{n}=96$ respectively).
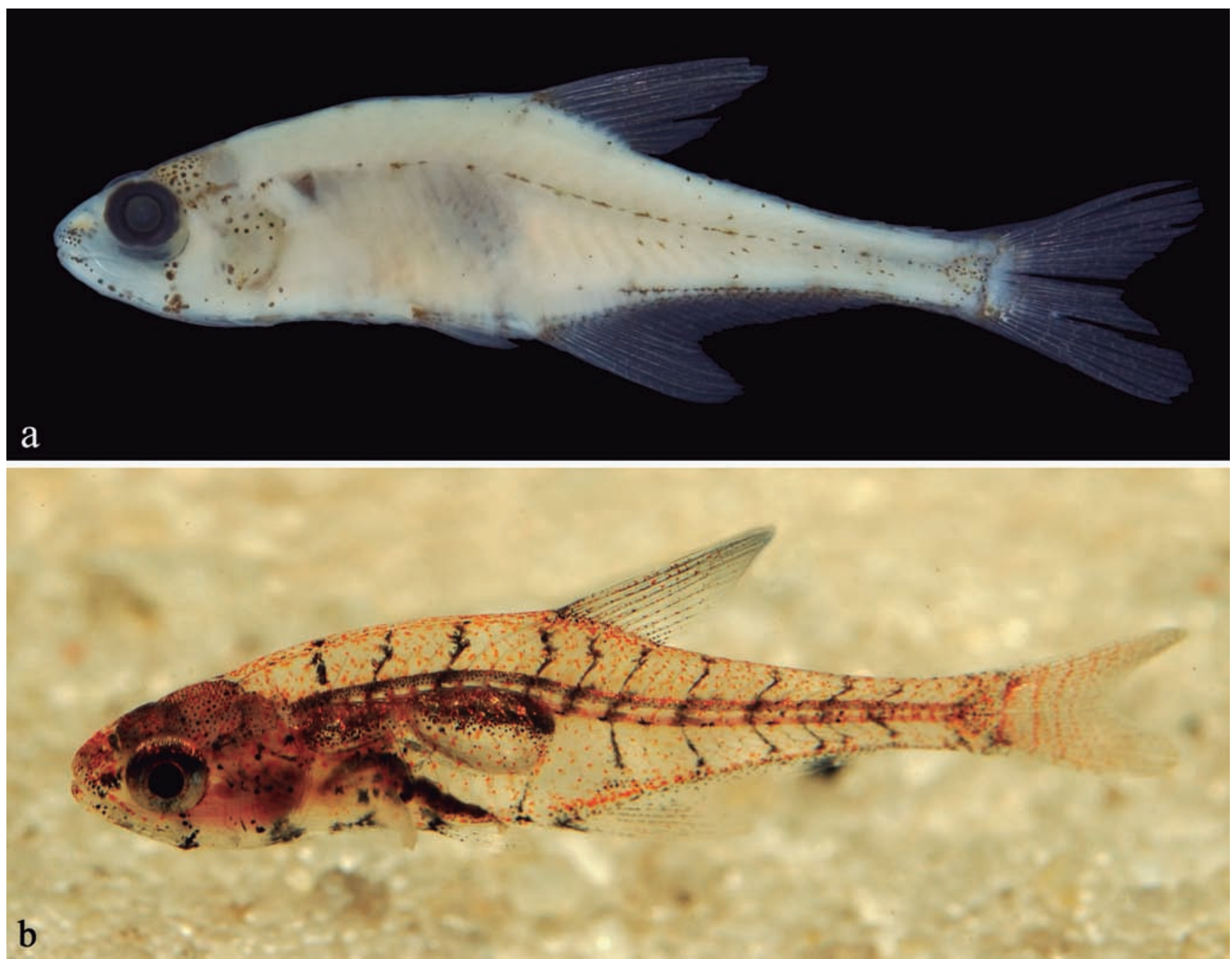

Fig. 1. Priocharax nanus, (a) holotype, MZUSP 114014, $13.8 \mathrm{~mm}$ SL; Brazil, Amazonas, Santa Isabel do Rio Negro, rio Negro basin, lake at right bank of rio Urubaxi, near igarapé Tapage; (b) live specimen, one of the paratypes, photographed right after capture. Photograph by Ralf Britz. 
Table 1. Morphometric data of Priocharax nanus $(n=25$, except for anal-fin length with $n=23$, range does not include holotype); $\mathrm{SD}=$ Standard Deviation.

\begin{tabular}{|c|c|c|c|c|}
\hline & holotype & range & mean & SD \\
\hline Standard length (SL) (mm) & 13.8 & $11.1-15.4$ & & - \\
\hline \multicolumn{5}{|c|}{ Percentages of SL } \\
\hline Depth at dorsal-fin origin & 26 & $21-27$ & 24.2 & 1.1 \\
\hline Snout to dorsal-fin origin & 53 & $52-55$ & 54.0 & 0.9 \\
\hline Snout to pelvic-fin origin & 40 & $38-42$ & 40.0 & 0.9 \\
\hline Snout to anal-fin origin & 53 & $52-55$ & 53.5 & 1.0 \\
\hline Dorsal-fin length & 25 & $24-28$ & 26.1 & 1.0 \\
\hline Dorsal-fin base & 12 & $11-14$ & 12.5 & 0.7 \\
\hline Pelvic-fin length & 13 & $11-14$ & 12.5 & 0.8 \\
\hline Anal-fin length & 23 & $21-25$ & 22.8 & 1.0 \\
\hline Anal-fin base & 33 & $31-36$ & 33.4 & 1.2 \\
\hline Caudal-peduncle depth & 8 & $7-9$ & 7.9 & 0.6 \\
\hline Caudal-peduncle length & 17 & $14-17$ & 15.0 & 0.9 \\
\hline Head length (HL) & 25 & $25-27$ & 25.4 & 0.6 \\
\hline \multicolumn{5}{|c|}{ Percentages of HL } \\
\hline Orbital diameter & 38 & $34-39$ & 36.4 & 1.2 \\
\hline Interorbital distance & 32 & $24-32$ & 27.8 & 2.2 \\
\hline Snout length & 24 & $19-25$ & 22.2 & 1.5 \\
\hline Upper jaw length & 53 & $46-55$ & 50.8 & 2.5 \\
\hline $\begin{array}{l}\text { Caudal peduncle depth as } \\
\text { percent of caudal peduncle } \\
\text { length }\end{array}$ & 48 & $42-61$ & 53.0 & 4.7 \\
\hline
\end{tabular}

Description. For overall appearance see Figure 1. Morphometric data provided in Table 1.

Body laterally compressed. Greatest body depth at vertical through dorsal-fin origin. Dorsal-fin origin approximately at midbody, at vertical through anal-fin origin. Pelvic-fin origin approximately midway between posterior margin of opercle and anal-fin origin. Dorsal profile of head and body gently convex from tip of snout to dorsal-fin origin. Dorsal profile of body along dorsal-fin base nearly straight, gently sloping posteroventrally; straight and posteroventrally inclined from latter point to caudal peduncle. Dorsal profile of caudal peduncle gently concave to base of dorsal procurrent rays. Ventral profile of head and body gently convex from symphysis of lower jaw to vertical through pectoral-fin origin; straight to slightly convex from latter point to pelvic-fin origin. Ventral profile of body posteroventrally inclined from pelvic-fin to anal-fin origin; straight and posterodorsally slanted along anterior one-half of anal-fin base, gently concave from latter point to base of ventral procurrent rays. Caudal peduncle elongate. Pseudotympanum present, located anterior to rib of fifth vertebra.

Snout blunt in lateral view. Eye about one-third of head length. Infraorbitals 1 to 6 and supraorbital absent, antorbital present. Mouth terminal with lower jaw slightly included. Tip of maxilla elongate, posterior border reaching vertical through posterior border of pupil. Premaxillary teeth in single series with 23(2), 24(4), 25(2), 27(1), or 29(2) teeth. Maxilla with 32(1), 33(1), 34(1), 35(2), 36(2), 37(1), 38(1), 39(1), or 41(1) teeth. Dentary with 33(2), 34(1), 35(2), 36(1), 38(2), 39(2), or 40 (1) teeth. Dentary teeth in single series, with few anterior teeth slightly displaced anteriorly. All jaw teeth small, conical and lingually curved to a moderate extent (Fig. 2).
Dorsal-fin rays ii.8(2) or $9 *(35)$. Pectoral fin with larval structure (Fig. 3). Cartilaginous pectoral radial plate incompletely divided longitudinally, articulating anteriorly with vertically elongated scapulocoracoid cartilage and posteriorly with larval-like pectoral-fin fold supported only by actinotrichia. Pectoral-fin rays absent. Endoskeletal bones of pectoral girdle absent, exoskeletal part with posttemporal, supracleithrum, cleithrum and two postcleithra. Cleithrum with posteriorly directed process at region immediately below ventral tip of supracleithrum. Pelvic-fin rays i, $6 *$ in all specimens $(n=37)$. Posterior tip of pelvic fin falling short of origin of anal fin but extending slightly beyond anus. Analfin rays iv-v, 21(7), 22*(13), 23(12), 24(3), 25(1), or 26(1). Anal-fin margin concave with anterior elongate lobe and posterior section of short rays. Caudal-fin rays i,9,8,i (16), dorsal procurrent rays $8(8)$ or $9(3)$, ventral procurrent rays 6 (4) or 7 (7). Caudal fin forked. Adipose fin absent.

Squamation present in almost all specimens, but scales highly deciduous and easily lost during handling. Scales cycloid, very thin, with no obvious circuli or radii. Scales in midlateral row 28(1), 29(2), 30(2), 31(1), or 32(1); no canal bearing lateral-line scales on body. Scale rows between dorsal-fin origin and pelvic-fin origin $7(1)$ or $8(7)$. Scale rows around caudal peduncle 9(4) or 10(2). Predorsal scales typically absent with one or two scales just anterior to dorsal fin in few specimens. Scales restricted to base of caudal-fin rays, not covering caudal-fin lobes.

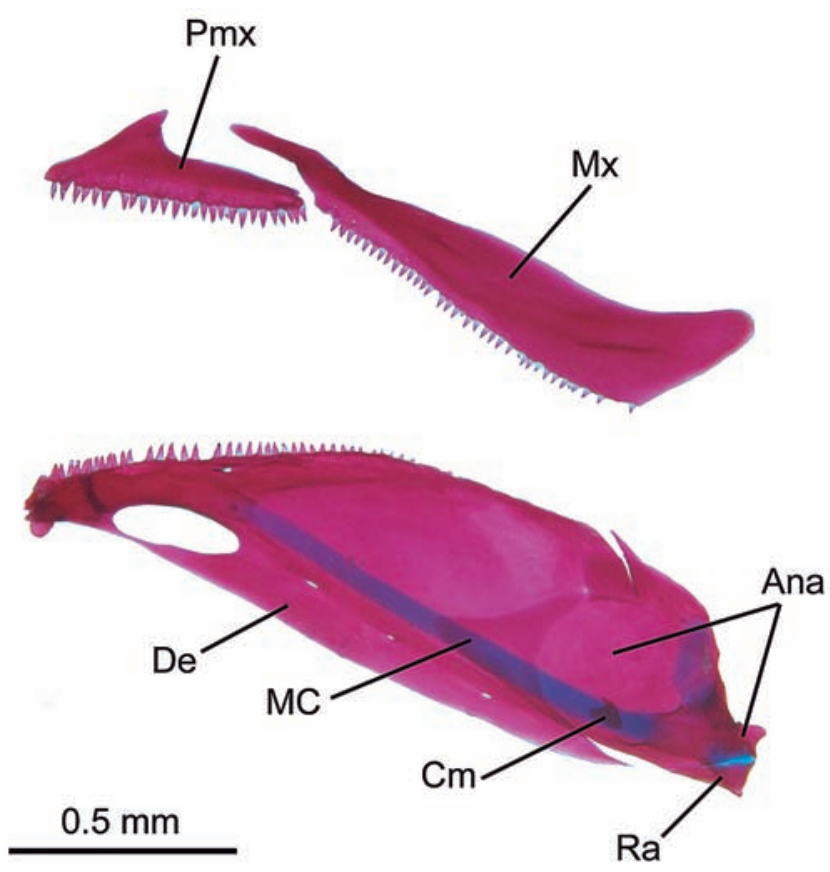

Fig. 2. Priocharax nanus, paratype, MZUSP 114018, 13.2 $\mathrm{mm} \mathrm{SL}$, c\&s; jaws in lateral view illustrating dentition. Ana $=$ anguloarticular; $\mathrm{Cm}=$ coronomeckelian; $\mathrm{De}=$ dentary; $\mathrm{MC}$ $=$ Meckel's cartilage; $\mathrm{Mx}=$ maxilla; $\mathrm{Pmx}=$ premaxilla; $\mathrm{Ra}=$ retroarticular. Scale bar $=0.5 \mathrm{~mm}$. 
Total vertebrae 32(2), 33(7), or 34(2); abdominal vertebrae 14(10) or 15(1); caudal vertebrae 18(3), 19(6), or 20(2). Upper limb gill-rakers 3(7) or 4(4), lower limb gill-rakers 9(6) or 10(5). Weberian apparatus well developed, all components ossified. Claustrum present as tiny, circular bone (Fig. 4). Large gap present between neural arches 3 and 4, with gap partially filled by dorsally projecting pointed process from vertebral centrum 3. Inner arm of os suspensorium large, projecting forward to vertical through middle of second centrum.

Color in alcohol. Overall ground color pale yellow (Fig. 1a). Patch of dark chromatophores present on dorsal portion of head and scattered dark chromatophores on opercle. Head with two dark stripes radiating from eye, one anteriorly to tip of snout and another ventrally. Line of dark chromatophores extends along dentary and on anterior tip of lower jaw. Iridophores present in orbit of some specimens. Longitudinal line of dark chromatophores along midlateral side of body. Triangular patch of dark chromatophores at base of caudal fin forming inconspicuous spot. Scattered dark chromatophores on posterior half of body, probably remnants of chevron-shaped dark thin lines present in live specimens. Dark chromatophores along predorsal midline forming two incomplete separate lines. Bases of anal-fin rays dark and forming irregular line along fin. Line of dark, more deeply located chromatophores slightly dorsal to base of anal-fin rays and also extending along fin base. Another dark line, dorsal and more superficial than latter, extending posteriorly from vertical through third to fourth branched anal-fin ray. These three lines more evident and better separated anteriorly and merging posteriorly. Three patches of dark chromatophores ventrally on body anterior to pelvic fin. Posteriormost patch elongated and located anterior to basipterygium, middle one more rounded and located at point of contact of contralateral pectoral girdles, anteriormost in form of a small spot on isthmus. Few dark chromatophores present in region around anus. Dark chromatophores at origins of dorsal, pelvic, and anal fins. All fins except pectoral with scattered dark chromatophores along borders of fin rays.

Color in life. Body mostly transparent (Fig. 1b). Pattern of distribution of dark chromatophores on head, along lateral sides of body, on caudal peduncle, and on all fins except pectoral as described above for color in alcohol. Dark chromatophores also scattered on dorsal surface of swim bladder and along anterior half of vertebral column. Approximately 10 vertical dark narrow bars along body from vertical through posterior margin of opercle to vertical through tip of posteriormost anal-fin ray, more or less evenly spaced and in a chevron-shaped pattern. Most narrow bars extend from dorsal to ventral margins of body, occasionally incomplete. Each bar W-shaped, following course of myoseptum. Numerous, tiny bright orange spots scattered over entire head and body, frequently forming longitudinal lines along anterior predorsal line and dorsal-fin base, anal-fin base and vertebral column. Patch of similar orange spots on dorsal surface of swim bladder and base of caudal fin. Orange spots forming approximately five vertical lines along caudal-fin rays, anterior lines better defined than more diffuse posterior lines. Orange spots scattered mainly along anterior four or five dorsal-fin rays. Iridophores covering swim bladder dorsally. Eye silvery, dorsal margin with dark and orange chromatophores.

Sexual dimorphism. Gonads not checked. Hooks absent in dorsal-, pectoral-, pelvic-, and anal-fins of all examined specimens $(\mathrm{n}=37)$.

Geographic distribution. Priocharax nanus is presently known from the rio Negro basin, Amazonas, Brazil (Fig. 5), in the surroundings of Santa Isabel do Rio Negro. The type locality near igarapé Tapaje is located in the rio Urubaxi basin, near its confluence with the rio Negro (Fig. 6). The new species was also collected from two other localities: one near the type locality in the rio Urubaxi, a right bank tributary of rio Negro and the other in a tributary of the left bank of the rio Negro. Specimens from a fourth locality also located in a tributary of the left margin of the rio Negro were only recorded from photographs. This locality (Igarapé Tibarrá, approximately $300 \mathrm{~m}$ above confluence with rio Negro, $0^{\circ} 26^{\prime} 28.4^{\prime \prime} \mathrm{S} 64^{\circ} 56^{\prime} 57.5^{\prime \prime} \mathrm{W}$ ) the western most point in the map on Fig. 5, is the nearest to Santa Isabel do Rio Negro.

Ecological notes. All specimens were collected between 9:00 and 17:00h, during the dry season (October), in the black acidic waters of the rio Negro basin. Three of the four localities were in shaded areas, close to the shore line where there was emergent and marginal vegetation. In the latter case trunks and branches were partially submerged (Fig. 6). Specimens were caught with dip nets around the submerged vegetation, at depths of approximately $1 \mathrm{~m}$ or less. In the other locality, located in the first tributary of the rio Negro above rio Daraá $\left(0^{\circ} 27^{\prime} 24.2^{\prime \prime}\right.$ S 64\%46'54), the vegetation on the river bank had been recently burnt and some newly grown submerged and emergent vegetation was present along with scattered tree trunks. The specimens were collected from an area exposed to the sun in warm, shallow water, approximately $50 \mathrm{~cm}$ deep.

Etymology. The species name is derived from the Latin, nanus, meaning a dwarf and alludes to the tiny size of adult specimens of the species. A noun in apposition. 


\section{Discussion}

Adults of Priocharax nanus retain the larval rayless structure of the pectoral fin characteristic of the other two species of the genus (Weitzman \& Vari, 1987). Weitzman \& Vari (1987) noted that species of Roeboides and Cynopotamus retained their larval pectoral fin structure in juveniles up to relatively large body sizes (i.e., 26 and $41 \mathrm{~mm} \mathrm{SL}$, respectively) and suggested that this feature could be a possible synapomorphy for an assemblage that included at least those three genera. Lucena (1998) analyzed this character in a broader context of the subfamily Characinae and hypothesized that the retention of a larval pectoral fin at larger body sizes is synapomorphic for a clade including Acanthocharax, Acestrocephalus, Charax, Cynopotamus, Galeocharax, Phenacogaster, and Roeboides. The Characinae (sensu Lucena, 1998 and Lucena \& Menezes, 2003) also included Priocharax, Gnathocharax, Heterocharax, Hoplocharax, and Lonchogenys. According to the scheme of phylogenetic relationships proposed for the Characinae by Lucena (1998), the retention of the larval pectoral fin in adults of Priocharax is autapomorphic for that genus, because Gnathocharax, Heterocharax, Hoplocharax, and Lonchogenys have a pectoral fin with the typical adult anatomical structure. Moreira et al. (2002) noted that the presence of a larval pectoral fin in the adult could be alternatively interpreted as a synapomorphy for the Characinae with a reversion in Gnathocharax, Heterocharax, Hoplocharax, and Lonchogenys, and in this case the retention of the larval pectoral fin in Priocharax would be primitive for the latter genus. A more recent assessment of the phylogenetic relationships of all those genera included Priocharax together with Gnathocharax, Heterocharax, Hoplocharax, Lonchogenys, within the Heterocharacini, a taxon not related to the Characinae (Mattox \& Toledo-Piza, 2012). In the context of the latter hypothesis, the ontogenetic retention of the larval pectoral fin in adults of Priocharax should be interpreted as autapomorphic for the genus. Within the Characidae, a retention of a larval pectoral fin at larger body sizes has been reported for Hyphessobrycon catableptus (Durbin) and H. moniliger Moreira, Lima \& Costa (Weitzman \& Vari, 1987; Moreira et al., 2002).

Priocharax nanus also has numerous small conical teeth in the upper and lower jaws arranged in a more or less irregular single row as in the other two congeners, $P$. ariel and $P$. pygmaeus. The number of dentary teeth was listed as a diagnostic character by Weitzman \& Vari (1987) to distinguish $P$. ariel from P. pygmaeus (38-55 vs. 2836 , respectively). Priocharax nanus has a dentary tooth count of 33-40, intermediate between that of $P$. ariel and $P$. pygmaeus with some overlap on each end of the range. Other meristic characters of $P$. nanus also show a similar degree of intermediateness and overlap with the other two species: premaxillary teeth (23-29, in P. nanus vs. 22-34 and 19-24 in $P$. ariel and $P$. pygmaeus, respectively); maxillary teeth (32-41, vs. 38-58 and 27-41) and upper limb gill rakers (3-4, vs. 3-5 and 2-3).

The color pattern of preserved specimens of Priocharax nanus is similar to that of $P$. ariel and P. pygmaeus. Recently collected specimens of Priocharax nanus have more dark chromatophores, but these fade away the longer they are in preservative. However, $P$. nanus seems to differ from both $P$. ariel and $P$. pygmaeus in life coloration, which is characterized by the presence of the vertical W-shaped dark lines along the body. Information about live coloration of Priocharax pygmaeus is largely missing with the exception of the statement that it was "transparent faint pink" in life (Weitzman $\&$ Vari, 1987: 648). Description of the life coloration of P. ariel was based on a large number of specimens without mention of the presence of vertical lines on the body by Weitzman \& Vari (1987).

Priocharax nanus is clearly a miniature species (sensu Weitzman \& Vari, 1988), with the largest specimen reaching $15.4 \mathrm{~mm} \mathrm{SL}$ ( $\mathrm{n}=26$ ). Like $P$. ariel and $P$. pygmaeus it also has a number of reductive anatomical characters associated with miniaturization such as the loss of the laterosensory canal system on the head and body, the loss of the bones of the infraorbital series and the presence of a gap in the Weberian apparatus between neural arches 3 and 4 (Weitzman \& Vari, 1987: fig 3; Mattox et al., 2013). However, P. nanus possesses more bones in the pectoral girdle and in the Weberian apparatus than do $P$. ariel and $P$. pygmaeus. In P. ariel and $P$. pygmaeus, the cleithrum, supracleithrum, and posttemporal are the only bones in the pectoral girdle (Weitzman \& Vari, 1987). In addition to those three pectoral girdle bones, $P$. nanus also has two postcleithra. Its ventral postcleithrum has the splintlike shape typical of postcleithrum 3 in many characiforms. The dorsal postcleithrum of $P$. nanus is a flat, relatively large bone located medial to the posterior process of the cleithrum. The dorsal margin of the bone contacts the ventral tip of the supracleithrum, a topographical position characteristic of postcleithrum 1 (e.g., Weitzman, 1962:74). The ventral margin of the dorsal postcleithrum is in contact with the dorsal tip of postcleithrum 3, which is, however, typical of postcleithrum 2. Based on its position only, it is therefore, unclear if the dorsal postcleithrum of $P$. nanus represents postcleithrum 1 or 2 . We noted that in characiforms that possess only two postcleithra, these are either postcleithra 1 and 2, or postcleithra 2 and 3, with no examples of a species with only postcleithra 1 and 3 (e.g., characters 132-134 of Zanata \& Vari, 2005; 247-249 of Mirande, 2010; and 122-124 of Mattox \& Toledo-Piza, 2012). Based on this observation, the flat large postcleithrum of $P$. nanus is most likely postcleithrum 2 , although additional information is necessary to better clarify the identity of this element. Among the Heterocharacini, species of Heterocharax, 


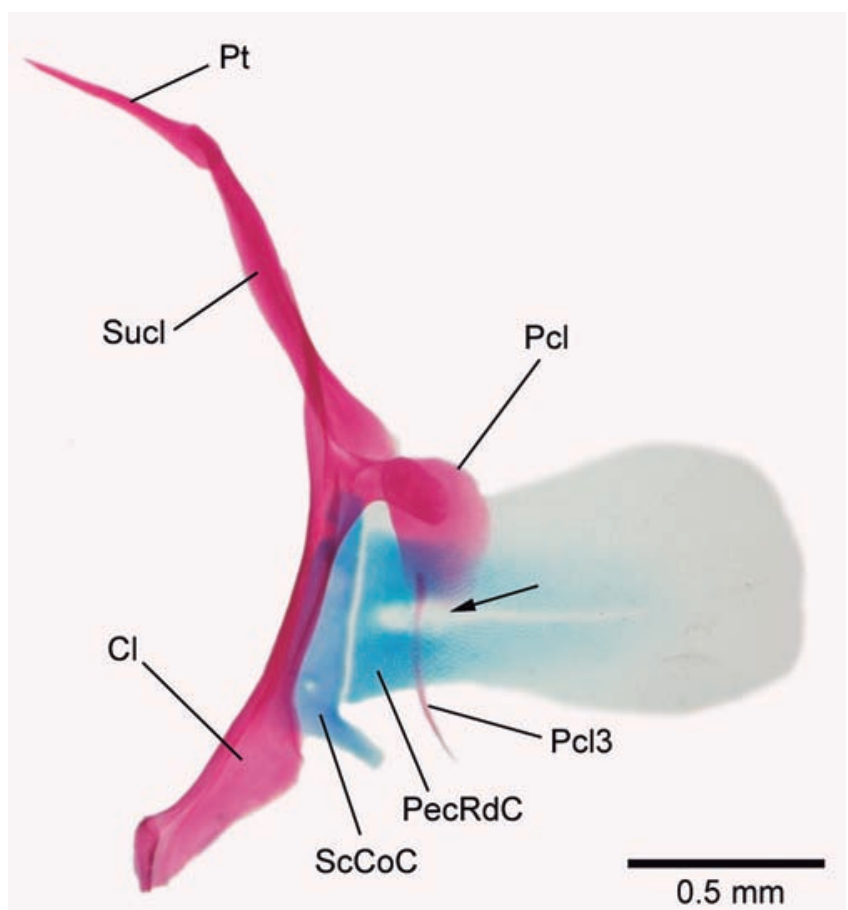

Fig. 3. Priocharax nanus, paratype, MZUSP 114015, 14.9 $\mathrm{mm}$ SL, c\&s; shoulder girdle in lateral view. $\mathrm{Cl}=$ cleithrum; $\mathrm{PecRdC}=$ pectoral-fin radial cartilage; $\mathrm{Pcl}=$ unidentified postcleithrum; $\mathrm{Pcl} 3=$ postcleithrum $3 ; \mathrm{Pt}=$ posttemporal; $\mathrm{ScCoC}=$ scapulocoracoid cartilage; Sucl $=$ supracleithrum . Arrow points to middle incision on pectoral-fin radial cartilage. Scale bar $=0.5 \mathrm{~mm}$.

Hoplocharax, and Lonchogenys all possess three postcleithra, and only Gnathocharax steindachneri Fowler lacks all three ossifications. The latter species, however, possesses a highly modified pectoral girdle with a well-developed and keeled coracoid, and the loss of postcleithra in that species could be related to this extreme modification.

The Weberian apparatus of Priocharax nanus is welldeveloped and similar to that of P. ariel and P. pygmaeus. In the latter two species all components are well ossified with the exception of the claustrum (Weitzman \& Vari, 1987). In $P$. nanus instead, the claustrum is clearly present, although poorly ossified. Priocharax ariel and $P$. pygmaeus share with $P$. nanus the gap between neural arches 3 and 4, with the gap partially filled by a dorsally projecting pointed process from vertebral centrum 3, a feature not described, however, but illustrated by Weitzman \& Vari (1987: fig. 3).

Even though Priocharax nanus is a miniature species, it shows fewer reductive characters, i.e., it has lost fewer bones in the skeleton compared to its two congeners. Although the presence of six branched pelvic-fin rays in $P$. nanus represents a reduction in comparison with the common condition of seven branched pelvic-rays rays in most members of the Characidae, it shows a less reduced state than P. ariel and P. pygmaeus which have only five branched pelvic-fin rays. Cyanogaster noctivaga is the only other characid that consistently has only five branched pelvic-fin rays (Mattox et al., 2013). On the other hand, other characids have six branched pelvic-fin rays (Mirande, 2010), and within the Heterocharacini (sensu Mattox \& Toledo-Piza, 2012) this condition is present in Hoplocharax goethei Géry contrary to Géry (1966:293) who mentioned: "ventrals probably i,7" (Toledo-Piza, pers. obs.). A few specimens of Gnathocharax steindachneri and of all three species of Heterocharax also may have only six branched pelvic-fin rays, while the vast majority of specimens of these species have seven branched-pelvic fin rays (ToledoPiza, 2000; Toledo-Piza, pers. obs.). All species of Roestes and Gilbertolus have seven branched pelvic-fin rays. These two genera together with the Heterocharacini were proposed to form a monophyletic taxon within the Characidae, the Heterocharacinae (sensu Mattox \& Toledo-Piza, 2012). Priocharax nanus shares with $P$. ariel and $P$. pygmaeus the presence of a pseudotympanum restricted to the region anterior to the rib of the fifth vertebra and the possession of the inner arm of the os suspensorium extending to a vertical through the second centrum and aligned in an approximately vertical plane, both characters interpreted as synapomorphic for the Heterocharacinae (sensu Mattox \& Toledo-Piza, 2012).

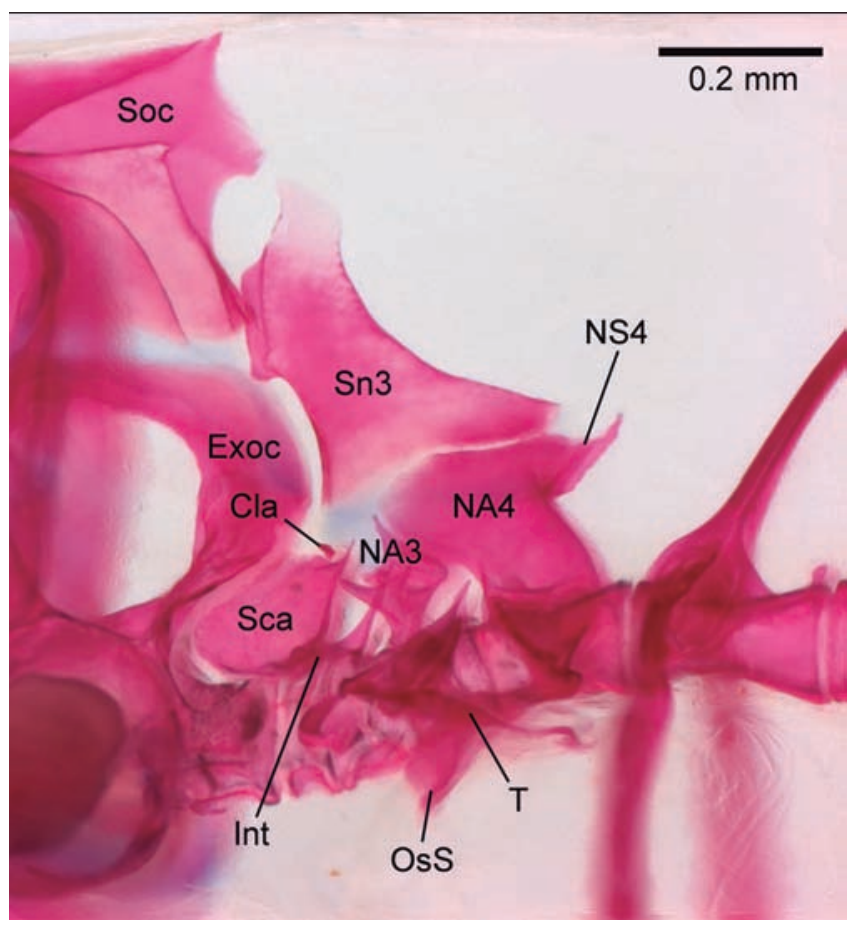

Fig. 4. Priocharax nanus, paratype, MZUSP 114015, $14.9 \mathrm{~mm}$ SL, c\&s; Weberian apparatus in lateral view. $\mathrm{Cla}=$ claustrum; Exoc $=$ Exoccipital; Int $=$ intercalarium; NA3-4 $=$ neural archs3-4; NS4 = neural spine 4; OsS = os suspensorium; Sca $=$ scaphium; $\mathrm{Sn} 3=$ supraneural $3 ; \mathrm{Soc}=$ supraoccipital $; \mathrm{T}=$ tripus. Scale bar $=0.2 \mathrm{~mm}$. 


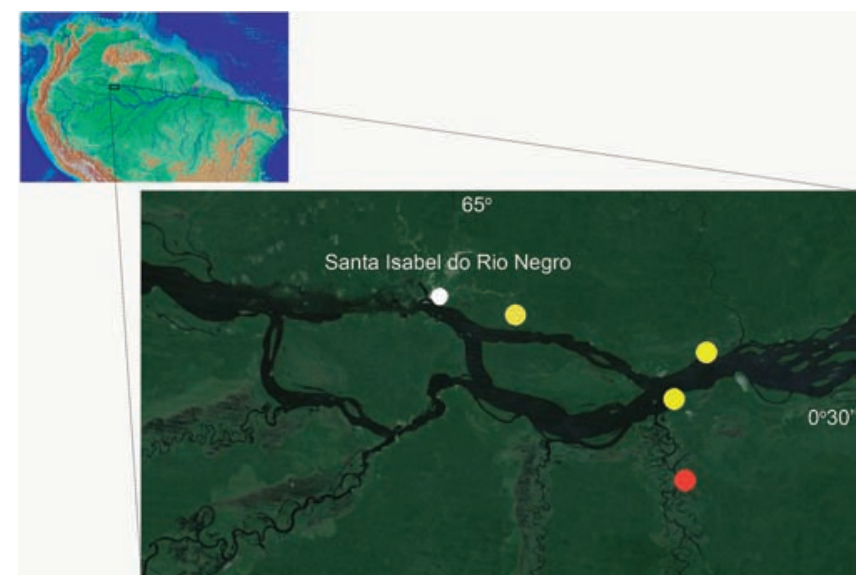

Fig. 5. Map of northern South America and surroundings of Santa Isabel do Rio Negro, rio Negro basin (detail), showing the distribution of Priocharax nanus. Type locality (red dot), other localities (yellow dots).

Whether the absence of the two postcleithra and the claustrum, and the presence of five branched pelvic-fin rays in Priocharax ariel and P. pygmaeus are indicative of a closer relationship between these two species relative to $P$. nanus is a question that is difficult to answer due to the fact that these characters are reductive in nature and could have been the result of independent cases of reduction (Weitzman \& Fink, 1983). A detailed study of relationships among the three species in search for potential progressive characters (sensu Britz \& Conway, 2009 ; i.e., derived character states relative to the last common ancestor of the taxon and that are not affected by developmental truncation) may highlight potential synapomorphies that could help understand the relationships among Priocharax species and the evolution of their reductive characters. In order to carry out such a study, more properly preserved, recently collected specimens, especially of $P$. pygmaeus, would be necessary. In the absence of any other data, however, such reductions could be tentatively used to support a hypothesis of a sister group relationship of $P$ ariel and $P$. pygmaeus.

With the description of Priocharax nanus another species can be added to the list of miniature Neotropical freshwater fishes. A total of 213 species are included in our list (Appendix I), a major increase from the 85 species listed by Weitzman \& Vari (1988), the first attempt to summarize information on miniature species within the South American freshwater fish fauna. Subsequently, Costa \& Le Bail (1999) updated Weitzman \& Vari's (1988) list and added 24 species. Sixteen species of those originally listed were not included in our list (Appendix II). Specimens larger than $26 \mathrm{~mm}$ SL were recorded for 14 of those 16 species, 13 originally listed by Weitzman \& Vari (1988) and one by Costa \& Le Bail (1999). In addition, two species names have since been synonymized with other species in the list of Weitzman \& Vari (1988). Since the last update made by Costa \& Le Bail (1999), 50 miniature Neotropical freshwater fishes have been described.
The largest diversity of miniature Neotropical freshwater fishes is still represented by the Characiformes ( 87 species, comprising $40.8 \%$ ). We added 40 characiform species to the list, almost doubling the number previously listed by Weitzman \& Vari (1988) and Costa \& Le-Bail (1999). As noted by Weitzman \& Vari (1988), it is interesting that miniature species are restricted to only a few families within the order, the Characidae and the Lebiasinidae in their account (with members of the Characidiinae listed by them in the Characidae, currently classified within the Crenuchidae). In our current list, the family Characidae accounts for the bulk of miniature characiform species (67 of the 87 miniatures), followed by the Crenuchidae, with 15 miniatures. The Lebiasinidae is represented by only three miniatures. Weitzman \& Vari (1988) also included three lebiasinid species in their list, however Nannostomus marginatus Eigenmann originally listed by those authors was not included in our list, following Weitzman \& Weitzman (2003:245) who recorded the species as reaching $35 \mathrm{~mm}$ SL. Nannostomus britskii Weitzman was included in our list based on Weitzman \& Weitzman's (2003:244) record of its maximum length of $24 \mathrm{~mm}$ SL. Weitzman \& Vari (1988) mentioned that within the Gasteropelecidae, several species of Carnegiella display numerous apparently paedomorphic features but did not include them in their list of miniatures. More recently (Weitzman \& Palmer, 2003:101) recorded the maximum lengths of Carnegiella myersi Fernández-Yépez and C. schereri Fernández-Yépez as 21.5 and $26.0 \mathrm{~mm} \mathrm{SL}$, respectively, and based on that information these two species were included in our list. Hence, within the Characiformes, miniature Neotropical freshwater fishes are now represented in the families Characidae, Crenuchidae, Gasteropelecidae, and Lebiasinidae.

A major increase in the number of miniature species is noted in the order Cyprinodontiformes, represented by 62 species in our list. Five species were originally listed by Weitzman \& Vari (1988) and Costa \& Le Bail (1999) later added 13 more. Of those 18 species we excluded Phallotorynus jucundus Ihering, a poeciliid recorded to reach up to $29.7 \mathrm{~mm}$ SL (Lucinda et al., 2005). Forty-two cyprinodontiform species were added to our list based mainly on information provided by Lucinda (2003). As a consequence the Cyprinodontiformes now represent $29.1 \%$ of the total miniatures (compared to almost $6 \%$ listed by Weitzman and Vari, 1988) exceeding the number of miniatures recorded for the Siluriformes. The latter order includes 52 miniatures or $24.4 \%$ of the total. Interestingly, within siluriforms there was a significant increase in the number of families that include miniatures, from the original six families in Weitzman \& Vari's (1988) list to 11 in our updated list (Appendix I). From the previous 33 siluriform miniatures listed by Weitzman and Vari (1988) and Costa \& Le Bail (1999), eight were excluded based on more recent records of their maximum length and 27 species were 
added. In a recent list of smallest known loricariids, Ribeiro et al. (2012) listed five miniatures, all of them included in the present list except for Corumbataia britskii Ferreira \& Ribeiro, which has been recorded as reaching $27 \mathrm{~mm}$ SL (Ferreira \& Ribeiro, 2007).

Finally, 10 miniatures are included from the families Cichlidae (3) Eleotridae (6) and Gobiidae (1). From those, only three species of eleotrids were previously listed (Weitzman \& Vari, 1988), of which Microphilypnus amazonicus Myers was excluded by us because it was considered to be a synonym of M. macrostoma Myers (Caires \& Figueiredo, 2011). Within Clupeiformes, miniatures are still represented only by two engraulid species, Amazonsprattus scintilla Roberts and Anchoviella manamensis Cervigón.

Published lists of miniature freshwater fishes are available for other continental regions of the world. More than 50 miniature freshwater species occur in South and Southeast Asia (Kottelat \& Vidthayanon, 1993), 24 miniature species were listed by Conway \& Moritz (2006) for Africa, and there are only seven miniatures in freshwaters of North America (Bennett \& Conway, 2010). Even though those lists are clearly out of date for some areas, with more miniatures having been described for example in Asia (Kottelat et al., 2006; Britz 2009; Britz et al., 2009; 2012; Conway et al., 2011) the diversity of miniature freshwater fishes in the Neotropical region exceeds by far that of other continents for which similar lists have been compiled.

Weitzman \& Vari (1988) also considered size at maturity (under $20 \mathrm{~mm} \mathrm{SL}$ ) as a criterion to include the species in their list of miniatures even if the species was known to exceed the $26 \mathrm{~mm}$ SL cut-off point, a procedure that was followed later by Kottelat \& Vidthayanon (1993). In both cases the maximum sizes exceeding $26 \mathrm{~mm}$ SL were recorded from aquarium specimens. If only maximum known size was used as criterion, only one of the seven species listed by Bennett \& Conway (2010) would be considered as miniature. The problems related to adhering strictly to the criterion of small body size were also discussed by Weitzman \& Vari (1988) and Conway \& Moritz (2006) in the case of species that exceed the cut-off size but exhibit paedomorphic features.

Another aspect related to using only size as criterion to compile lists of miniature freshwater fishes is that although new species are discovered and added to revised lists of miniatures, other species reported to exceed the cut-off size limit will have to be excluded. Conway \& Moritz (2006) suggested that in the case of African miniature freshwater fishes although there may be a turnover in the taxa included in the list, the overall number of taxa listed would probably remain relatively constant through time. This is clearly not the case for the Neotropical miniature freshwater fish species. Fourteen species were excluded from the previous lists of Weitzman \& Vari (1988) and Costa \& Le Bail (1999), currently

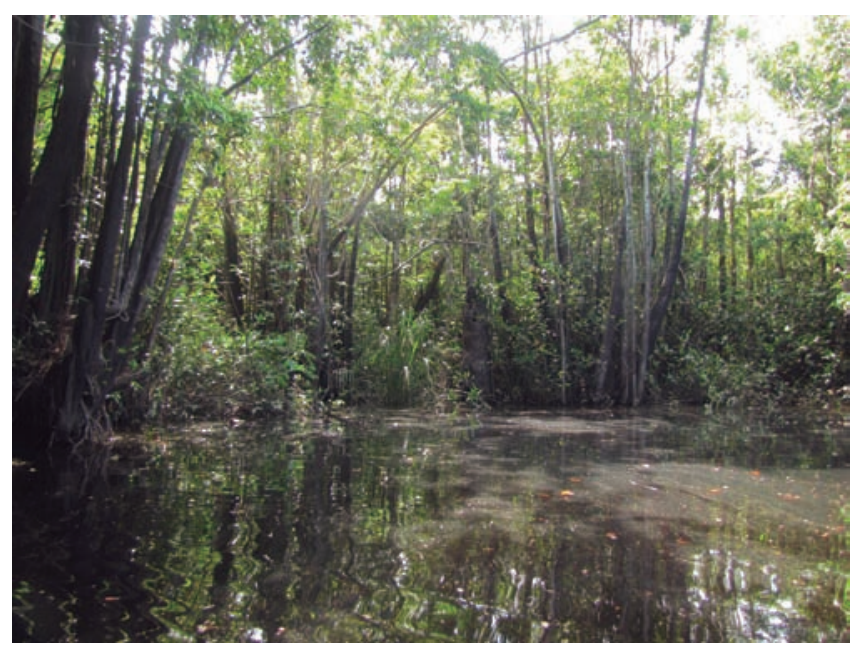

Fig. 6. Lake at right bank of rio Urubaxi, near igarapé Tapage, rio Negro, the type locality of Priocharax nanus. Photograph by Manoela M. F. Marinho.

known to exceed $26 \mathrm{~mm} \mathrm{SL}$, compared to 118 species that were added to the list, resulting in a markedly increase in the total number of miniatures freshwater fishes currently known for the Neotropical region.

After more than 25 years since the publication of Weitzman \& Vari's (1988) list of miniature South American freshwater fishes, their statement that "The pace of description of such miniature species has quickened in the last decade and recent collecting efforts in various regions of South America revealed the existence of many interesting miniature species", is still true. In addition, aspects other than body size that may be used as criteria for distinguishing miniatures, such as size at maturity and the presence in miniatures of characters of a reductive nature, remain largely unknown for most species. In that context it would be interesting, for example, to explore which of the many miniature species represent proportional dwarfs and which are the result of developmental truncation (sensu Britz \& Conway, 2009). Many other aspects of miniature fishes are yet to be explored in future studies of taxonomy, systematics, and developmental biology. We hope that this paper will stimulate further efforts towards the study of miniature Neotropical freshwater fishes.

Comparative material. Priocharax ariel: Brazil: Amazonas, Santa Isabel do Rio Negro, rio Negro basin: MZUSP 39778, 4, 13.5-14.6 mm SL, rio Urubaxi; MZUSP 55099, 8, 12.4-14.2 mm SL, igarapé at São João, near Santa Isabel do Rio Negro; MZUSP 55097, 4 of 6, 12.2-12.7 mm SL, lagoon near Paricatuba; MZUSP 62230, 2 of 4, 15.1-15.2 mm SL, lagoon in island near Paricatuba. Venezuela: Territorio Federal Amazonas: MZUSP 36497, 50, 11.8-15.2 mm SL, MZUSP 55142, 12 paratypes, 12.0-14.7 mm SL (5 c\&s, 12.0-14.0 mm SL), Caño Manu, tributary of río Casiquiare approximately $250 \mathrm{~m}$ upstream from Solano. Priocharax pygmaeus: Colombia: Departamento Amazonas: MZUSP 36498, 5 paratypes, 10.2-10.7 mm SL, Quebrada Parajito, tributary 
of Quebrada Bacada, tributary of Quebrada Matamata, tributary of río Amazonas, northwest of Leticia, about $04^{\circ} 41^{\prime}$ 'S 69²57'W. Peru: Loreto, Requena, río Ucayali basin: MZUSP 85644, 1, $16.5 \mathrm{~mm}$ SL, small "quebrada", tributary of Quebrada Fierro Caño, ca. 4 km North of IIAP (2.7 km east of Jenaro Herrera).

\section{Acknowledgments}

This work was carried out at the Departamento de Zoologia, Instituto de Biociências, Universidade de São Paulo, Brazil (IBUSP) and the Zoology Department, Natural History Museum, London, UK. Both institutions are acknowledged for providing work space and access to facilities. The authors are grateful to Manoela M. F. Marinho (MZUSP), Sr. Carlos and Sra. Raimunda de Jesus Machado for assistance during fieldwork. Colleagues from INPA, especially Jansen Zuanon, Lúcia Rapp Py-Daniel, Marcelo Rocha, and Renildo Oliveira, provided important support for the fieldtrip and/ or curatorial support. The collecting permit was granted by the Instituto Brasileiro do Meio Ambiente e dos Recursos Naturais Renováveis - IBAMA (permit nº. 26281-1 to MTP). Osvaldo T. Oyakawa, Michel D. Gianeti (MZUSP), and Jeffrey Clayton (USNM) provided curatorial support. The miniature list benefited from discussions and/or information provided by Kevin W. Conway, Richard P. Vari, Scott A. Schaefer, Flávio C. T. Lima, Cristiano R. Moreira, José L. O. Mattos, Luisa M. Sarmento-Soares, Paulo H. F. Lucinda, Rodrigo A. Caires, and Fernando Carvalho. The map was prepared with the help of a tutorial available at http://wikipeixes.com.br. Henrique R. Varella, Kleber M. Leite, and Murilo Carvalho provided help with computer programs. We thank Richard P. Vari and one anonymous reviewer for critically reviewing the manuscript. The fieldtrip was partially supported by a grant from Fundação de Amparo à Pesquisa do Estado de São Paulo - FAPESP (proc. no . 2011/13735-3 to MTP). GMTM was financially supported by a postdoctoral fellowship (FAPESP proc. $n^{\circ} .2010 / 50941-8$ ) and an international internship grant (FAPESP proc. $\mathrm{n}^{\circ}$. 2012/01075-1). MTP acknowledges partial funding from Conselho Nacional de Desenvolvimento Científico e Tecnológico - CNPq (proc. nº 307067/2010-6). This study also benefitted from Projeto Saci - South American Characiformes Inventory (FAPESP proc. nº. 2011/50282-7, http://www.projeto-saci.com).

\section{Literature Cited}

Bennett, M. G. \& K. W. Conway. 2010. An overview of North America's diminutive freshwater fish fauna. Ichthyological Exploration of Freshwaters, 21: 63-72.

Bockmann, F. A. \& G. M. Guazzelli. 2003. Family Heptapteridae. Pp. 406-431. In: Reis, R. E., S. O. Kullander, C. J. Ferraris Jr. (Eds.). Check list of the freshwater fishes of South and Central America. Porto Alegre, RS, Edipucrs.
Britto, M. R. \& C. R. Moreira. 2002. Otocinclus tapirape: a new hypoptopomatine catfish from Central Brazil (Siluriformes: Loricariidae). Copeia, 2002: 1063-1069.

Britz, R. 2009. Danionella priapus, a new species of miniature cyprinid fish from West Bengal, India (Teleostei: Cypriniformes: Cyprinidae). Zootaxa, 2277: 53-60.

Britz, R. \& K. W. Conway. 2009. Osteology of Paedocypris, a miniature and highly developmentally truncated fish (Teleostei: Ostariophysi: Cyprinidae). Journal of Morphology, 270: 389-412.

Britz, R., K. W. Conway \& L. Rüber. 2009. Spectacular morphological novelty in a miniature cyprinid fish, Danionella dracula n. sp. Proceedings of the Royal Society, B, 276: 2179-2186.

Britz, R., M. Kottelat \& H. H. Tan. 2012. Fangfangia spinicleithralis, a new genus and species of miniature cyprinid from the peat swamp forests of Borneo (Teleostei: Cypriniformes: Cyprinidae). Ichthyological Exploration of Freshwaters, 22: 327-335.

Buckup, P. A. 2003. Family Crenuchidae. Pp. 87-95. In: Reis, R. E., S. O. Kullander, C. J. Ferraris Jr. (Eds.). Check list of the freshwater fishes of South and Central America. Porto Alegre, RS, Edipucrs.

Bührnheim, C. M., T. P. Carvalho, L. R. Malabarba \& S. H. Weitzman. 2008. A new genus and species of characid fish from the Amazon basin - the recognition of a relictual lineage of characid fishes (Ostariophysi: Cheirodontinae: Cheirodontini). Neotropical Ichthyology, 6: 663-678.

Caires, R. A. 2013. Microphilypnus tapajosensis, a new species of eleotridid from the Tapajós basin, Brazil (Gobioidei: Eleotrididae). Ichthyological Exploration of Freshwaters, 24: 155-160.

Caires, R. A. \& J. L. Figueiredo. 2011. Review of the genus Microphilypnus Myers, 1927 (Teleostei: Gobioidei: Eleotridae) from the lower Amazon basin, with description of one new species. Zootaxa, 3036: 39-57.

Carvalho, F. R., G. C. de Jesus \& F.Langeani . 2014. Redescription of Hyphessobrycon flammeus Myers, 1924 (Ostariophysi: Characidae), a threatened species from Brazil. Neotropical Ichthyology, 12:247-256.

Casatti, L., F. R. Carvalho, J. L. Veronezi Jr. \& D. R. Lacerda. 2006. Reproductive biology of the neotropical superfetaceous Pamphorichthys hollandi (Cyprinodontiformes: Poeciliidae). Ichthyological Exploration of Freshwaters, 17: 59-64.

Conway K. W. \& R. Britz. 2007. Sexual dimorphism of the Weberian apparatus and pectoral girdle in Sundadanio axelrodi (Ostariophysi: Cyprinidae), a miniature cyprinid from South East Asia. Journal of Fish Biology, 71: 1562-1570.

Conway, K. W., M. Kottelat \& H. H. Tan. 2011. Review of the Southeast Asian miniature genus Sundadanio (Ostariophysi: Cyprinidae) with descriptions of seven new species from Indonesia and Malaysia. Ichthyological Exploration of Freshwaters, 22: 251-288.

Conway, K. W. \& T. Moritz. 2006. Barboides britzi, a new species of miniature cyprinid from Benin (Ostariophysi: Cyprinidae), with neotype designation for B. gracilis. Ichthyological Exploration of Freshwaters, 17: 73-84.

Costa, W. J. E. M. 2002. Leptolebias marmoratus (Cyprinodontiformes: Rivulidae: Cynolebiatinae): rediscovery and redescription of a rare, miniaturized forest dwelling seasonal fish from Southeastern Brazil. Ichthyological Exploration of Freshwaters 13: 379-384.

Costa, W. J. E. M. 2003a. Rivulus paracatuensis n. sp. (Cyprinodontiformes: Rivulidae): a new rivuline species from the Rio São Francisco basin, Brazil. Aqua, Journal of Ichthyology and Aquatic Biology, 7: 39-43.

Costa, W. J. E. M. 2003b. A new miniature rivuline fish from the upper Negro river basin, northern Brazil (Teleostei, Cyprinodontiformes, 
Rivulidae). Arquivos do Museu Nacional, Rio de Janeiro, 61: 175-178.

Costa, W. J. E. M. 2004a. Rivulus kirovski, a new killifish from the central Amazon, Brazil (Cyprinodontiformes: Rivulidae). Neotropical Ichthyology, 2: 9-12.

Costa, W. J. E. M. 2004b. Rivulus uatumani sp. n. (Teleostei: Cyprinodontiformes: Rivulidae): a new miniature killifish from the central Brazilian Amazon. Zootaxa, 696: 1-8.

Costa, W. J. E. M. 2005. Seven new species of the killifish genus Rivulus (Cyprinodontiformes: Rivulidae) from the Paraná, Paraguay and upper Araguaia river basins, central Brazil. Neotropical Ichthyology, 3: 69-82.

Costa, W. J. E. M. 2007. Simpsonichthys nigromaculatus, a new miniature seasonal killifish from the upper Rio Paraná basin, central Brazil (Teleostei: Cyprinodontiformes: Rivulidae). Ichthyological Exploration of Freshwaters, 18: 199-203.

Costa, W. J. E. M. 2008. Monophyly and taxonomy of the Neotropical seasonal killifish genus Leptolebias (Teleostei: Aplocheiloidei: Rivulidae), with the description of a new genus. Zoological Journal of the Linnean Society, 153: 147-160.

Costa, W. J. E. M. \& P. F. Amorim. 2013. Delimitation of cryptic species of Notholebias, a genus of seasonal miniature killifishes threatened with extinction from the Atlantic Forest of southeastern Brazil (Cyprinodontiformes: Rivulidae). Ichthyological Exploration of Freshwaters, 24: 63-72.

Costa, W. J. E. M. \& F. A. Bockmann. 1994. Typhlobelus macromycterus, a new blind glanapterygine fish (Siluriformes Trichomycteridae) from the Rio Tocantins, Brazil. Tropical Zoology, 7: 67-72.

Costa, W. J. E. M. \& P. H. N. Bragança. 2013. A new miniature killifish of the genus Laimosemion, subgenus Owiyeye, from the Negro river drainage, Brazilian Amazon (Cyprinodontiformes: Rivulidae). Ichthyological Exploration of Freshwaters, 24: 93-96.

Costa, W. J. E. M. \& H. Lazzarotto. 2014. Laimosemion ubim, a new miniature killifish from the Brazilian Amazon (Teleostei: Rivulidae). Ichthyological Exploration of Freshwaters, 24: 371-378.

Costa, W. J. E. M. \& P.-Y. Le Bail. 1999. Fluviphylax palikur: a new poeciliid from the Rio Oiapoque basin, Northern Brazil (Cyprinodontiformes: Cyprinodontoidei), with comments on miniaturization in Fluviphylax and other Neotropical freshwater fishes. Copeia, 1999: 1027-1034.

Costa, W. J. E. M., C. R. Moreira \& F. C. T. Lima. 2003. Simpsonichthys cholopteryx n. sp. (Cyprinodontiformes: Rivulidae: Cynolebiatinae): a new dwarf annual fish from the upper Rio Araguaia basin, central Brazil. Aqua, Journal of Ichthyology and Aquatic Biology, 6: 139-144.

Costa, W. J. E. M. \& D. T. B. Nielsen. 2003. Simpsonichthys reticulatus $\mathrm{n}$. sp. (Cyprinodontiformes: Rivulidae): a new annual fish from the Rio Xingu floodplains, Brazilian Amazon. Aqua, Journal of Ichthyology and Aquatic Biology, 7: 119-122.

Dutra, G. M., W. B. Wosiacki \& M. C. C. de Pinna. 2012. Trichomycterus anhanga, a new species of miniature catfish related to $T$. hasemani and $T$. johnsoni (Siluriformes: Trichomycteridae) from the Amazon basin, Brazil. Neotropical Ichthyology, 10: 225-231.

Ferreira, K. M. \& A. C. Ribeiro. 2007. Corumbataia britskii (Siluriformes: Loricariidae: Hypoptopomatinae) a new species from the upper Rio Paraná basin, Mato Grosso do Sul, Central Brazil. Zootaxa, 1386: 59-68.

Figueiredo, C. A. 2008. A new Pamphorichthys (Cyprinodontiformes: Poeciliidae: Poeciliini) from central Brazil. Zootaxa, 1918: 59-68. Fink, W. L. \& S. H. Weitzman. 1974. The so-called cheirodontin fishes of Central America with descriptions of two new species (Pisces: Characidae). Smithsonian Contributions to Zoology, 172: 1-46.

Friel, J. P. 2003. Family Aspredinidae. Pp. 261-267. In: Reis, R. E., S. O. Kullander, C. J. Ferraris Jr. (Eds.). Check list of the freshwater fishes of South and Central America. Porto Alegre, RS, Edipucrs.

Géry J. 1966. Hoplocharax goethei, a new genus and species of South American characoid fishes, with a review of the sub-tribe Heterocharacini. Ichthyologica 38: 281-296.

Géry, J. \& U. Römer. 1997. Tucanoichthys tucano gen. n. sp. n., a new miniature characid fish (Teleostei: Characiformes: Characidae) from the Rio Uaupes basin in Brazil. Aqua, Journal of Ichthyology and Aquatic Biology, 2: 65-72.

Kottelat, M., R. Britz, T. H. Hui \& K. E. Witte. 2006. Paedocypris, a new genus of Southeast Asian cyprinid fish with a remarkable sexual dimorphism, comprises the world's smallest vertebrate. Proceedings of the Royal Society B: Biological Sciences, 273: 895-899.

Kottelat, M. \& C. Vidthayanon. 1993. Boraras micros, a new genus and species of minute freshwater fish from Thailand (Teleostei: Cyprinidae). Ichthyological Exploration of Freshwaters, 4: 161-176.

Kullander, S. O. 2003a. Family Cichlidae. Pp. 605-654. In: Reis, R. E., S. O. Kullander, C. J. Ferraris Jr. (Eds.). Check list of the freshwater fishes of South and Central America. Porto Alegre, RS, Edipucrs.

Kullander, S. O. 2003b. Family Gobiidae. Pp. 657-665. In: Reis, R. E., S. O. Kullander, C. J. Ferraris Jr. (Eds.). Check list of the freshwater fishes of South and Central America. Porto Alegre, RS, Edipucrs.

Lehmann, P., H. Lazzarotto \& R. E. Reis. 2014. Parotocinclus halbothi, a new species of small armored catfish (Loricariidae: Hypoptopomatinae), from the Trombetas and Marowijne River basins, in Brazil and Suriname. Neotropical Ichthyology, 12: 27-33.

Lima, F. C. T., L. R. Malabarba, P. A. Buckup, J. F. P. da Silva, R. P. Vari, A. Harold, R. Benine, O. T. Oyakawa, C. S. Pavanelli, N. A. Menezes, C. A. S. Lucena, M. C. S. L. Malabarba, Z. M. S. Lucena, R. E. Reis, F. Langeani, L. Casatti, V. A. Bertaco, C. Moreira \& P. H. F. Lucinda. 2003. Genera incertae sedis in Characidae. Pp. 106-169. In: Reis, R. E., S. O. Kullander, C. J. Ferraris Jr. (Eds.). Check list of the freshwater fishes of South and Central America. Porto Alegre, RS, Edipucrs.

Lima, F. C. T. \& M. Toledo-Piza. 2001. New species of Moenkhausia (Characiformes: Characidae) from the Rio Negro of Brazil. Copeia, 2001: 1058-1063.

Lucena, C. A. S. 1998. Relações filogenéticas e definição do gênero Roeboides Günther (Ostariophysi, Characiformes, Characidae). Comunicações do Museu de Ciências e Tecnologia da PUCRS, série Zoologia, 11: 19-59.

Lucena, C. A. S. \& N. A. Menezes. 2003. Subfamily Characinae. Pp. 200-208. In: Reis, R. E., S. O. Kullander, C. J. Ferraris Jr. (Eds.). Checklist of the freshwater fishes of South and Central America. Porto Alegre, RS, Edipucrs.

Lucinda, P. H. F. 2003. Family Poeciliidae. Pp. 555-581. In: Reis, R. E., S. O. Kullander, C. J. Ferraris Jr. (Eds.). Check list of the freshwater fishes of South and Central America. Porto Alegre, RS, Edipucrs.

Lucinda, P. H. F., R. S. Rosa \& R. E. Reis. 2005. Systematics and biogeography of the genus Phallotorynus Henn, 1916 (Cyprinodontiformes: Poeciliidae: Poecillinae), with description of three new species. Copeia, 2005: 609-631.

Malabarba, L. R. 2003. Subfamily Cheirodotinae. Pp. 215-221. In: Reis, R. E., S. O. Kullander, C. J. Ferraris Jr. (Eds.). Check list of the freshwater fishes of South and Central America. Porto Alegre, RS, Edipucrs. 
Marinho, M. M. F., D. A. Bastos \& N. A. Menezes. 2013. New species of miniature fish from Marajó Island, Pará, Brazil, with comments on its relationships (Characiformes: Characidae). Neotropical Ichthyology, 11: 739-746.

Mattos, J. L. O., W. J. E. M. Costa \& C. S. Gama. 2008. A new miniature species of Ammoglanis (Siluriformes: Trichomycteridae) from the Brazilian Amazon. Ichthyological Exploration of Freshwaters, 19: 161-166.

Mattos, J. L. O. \& S. M. Q. Lima. 2010. Microcambeva draco, a new species from northeastern Brazil (Siluriformes: Trichomycteridae). Ichthyological Exploration of Freshwaters, 21: 233-238.

Mattox, G. M. T., R. Britz, M. Toledo-Piza \& M. M. F. Marinho. 2013. Cyanogaster noctivaga, a remarkable new genus and species of miniature fish from the Rio Negro, Amazon basin (Ostariophysi: Characidae). Ichthyological Exploration of Freshwaters, 23: 297-318.

Mattox, G. M. T. \& M. Toledo-Piza. 2012. Phylogenetic study of the Characinae (Teleostei: Characiformes: Characidae). Zoological Journal of the Linnean Society, 165: 809-915.

Mirande, J. M. 2010. Phylogeny of the family Characidae (Teleostei: Characiformes): from characters to taxonomy. Neotropical Ichthyology, 8: 385-568.

Moreira, C. R. 2005. Xenurobrycon coracoralinae, a new glandulocaudine fish (Ostariophysi: Characiformes: Characidae) from Central Brazil. Proceedings of the Biological Society of Washington, 118: 855-862.

Moreira, C. R., F. C. T. Lima \& W. J. E. M. Costa. 2002. Hyphessobrycon moniliger, a new characid fish from rio Tocantins basin, Central Brazil (Ostariophysi: Characiformes). Ichthyological Exploration of Freshwaters, 13: 73-80.

Netto-Ferreira, A. L., J. L. O. Birindelli \& P. A. Buckup. 2013a. A new miniature species of Characidium Reinhardt (Ostariophysi: Characiformes: Crenuchidae) from the headwaters of the rio Araguaia, Brazil. Zootaxa, 3664: 361-368.

Netto-Ferreira, A. L., J. L. O. Birindelli, L. M. Sousa, T. C. Mariguela \& C. Oliveira. 2013b. A new miniature characid (Ostariophysi: Characiformes: Characidae), with phylogenetic position inferred from morphological and molecular data. PLoS One, 8:e52098.

Oliveira, R. R., M. S. Rocha, M. B. Anjos, J. Zuanon \& L. H. R. Py-Daniel. 2009. Fish fauna of small streams of the CatuaIpixuna Extractive Reserve, State of Amazonas, Brazil. Check List, 5: 154-172.

Pezold, F. 1993. Evidence for a monophyletic Gobiinae. Copeia, 1993: 634-643.

de Pinna, M. C. C. \& W. Wosiacki. Family Trichomycteridae. Pp. 270-290. In: Reis, R. E., S. O. Kullander, C. J. Ferraris Jr. (Eds.). Check list of the freshwater fishes of South and Central America. Porto Alegre, RS, Edipucrs.

Reis, R. E. 2003. Family Callichthyidae. Pp. 291-309. In: Reis, R. E., S. O. Kullander, C. J. Ferraris Jr. (Eds.). Check list of the freshwater fishes of South and Central America. Porto Alegre, RS, Edipucrs.

Reis, R. E., S. O. Kullander \& C. J. Ferraris Jr. 2003. Check list of the freshwater fishes of South and Central America. Porto Alegre, Edipucrs.

Ribeiro, A. C., F. C. T. Lima \& E. H. L. Pereira. 2012. A new genus and species of a minute suckermouth armored catfish (Siluriformes: Loricariidae) from the Rio Tocantins drainage, central Brazil: the smallest known loricariid catfish. Copeia, 2012: 637-647.

Roberts, T. R. 2013. Leptophilypnion, a new genus with two new species of tiny central Amazonian gobioid fishes (Teleostei, Eleotridae). Aqua, International Journal of Ichthyology, 19: 85-98.
Rocha, M., H. Lazzarotto \& L. R. Py-Daniel. 2012. A new species of Scoloplax with a remarkable new tooth morphology within Loricarioidea (Siluriformes: Scoloplacidae). Copeia, 2012: 670-677.

Rocha, M. S., R. R. Oliveira \& L. H. R. Py-Daniel. 2008. Scoloplax baskini: a new spiny dwarf catfish from rio Aripuanã, Amazonas, Brazil (Loricarioidei: Scoloplacidae). Neotropical Ichthyology, 6: 323-328.

Román-Valencia, C., C. A. García-Alzate, R. C. Ruiz-C., D. C. Taphorn. 2012. A new species of Tyttocharax (Characiformes: Characidae: Stevardiinae) from the Güejar River, Orinoco River basin, Colombia. Neotropical Ichthyology, 10: 519-525.

Schaefer, S. A. 2003. Family Astroblepidae. Pp. 312-317. In: Reis, R. E., S. O. Kullander, C. J. Ferraris Jr. (Eds.). Check list of the freshwater fishes of South and Central America. Porto Alegre, RS, Edipucrs.

Schaefer, S. A., F. Provenzano, M. de Pinna \& J. N. Baskin. 2005. New and noteworthy Venezuelan glanapterygine catfishes (Siluriformes, Trichomycteridae), with discussion of their biogeography and psammophily. American Museum Novitates, 3496: 1-27.

Shibatta, O. A. 2003. Family Pseudopimelodidae. Pp. 401-405. In: Reis, R. E., S. O. Kullander, C. J. Ferraris Jr. (Eds.). Check list of the freshwater fishes of South and Central America. Porto Alegre, RS, Edipucrs.

Soares-Porto, L. M, S. J. Walsh, L. G. Nico \& J. M. Netto. 1999. A new species of Gelanoglanis from the Orinoco and Amazon river basins, with comments on miniaturization within the genus (Siluriformes: Auchenipteridae: Centromochlinae). Ichthyological Exploration of Freshwaters, 10: 63-72.

Sousa, L. M. \& L. H. R. Py-Daniel. 2005. Description of two new species of Physopyxis and redescription of $P$. lyra (Siluriformes: Doradidae). Neotropical Ichthyology, 3: 625-636.

Taylor, W. R. \& G. C. Van Dyke. 1985. Revised procedures for staining and clearing small fishes and other vertebrates for bone and cartilage study. Cybium, 9: 107-119.

Toledo-Piza, M. 2000. Two new Heterocharax species (Teleostei: Ostariophysi: Characidae), with a redescription of $H$. macrolepis. Ichthyological Exploration of Freshwaters, 11: 289-304.

Vari, R. P. \& C. J. Ferraris Jr. 2003. Family Cetopsidae. Pp. 257-260. In: Reis, R. E., S. O. Kullander, C. J. Ferraris Jr. (Eds.). Check list of the freshwater fishes of South and Central America. Porto Alegre, RS, Edipucrs.

Vari, R. P. \& C. J. Ferraris Jr. 2013. Two new species of the catfish genus Tatia (Siluriformes: Auchenipteridae) from the Guiana shield and a reevaluation of the limits of the genus. Copeia, 2013: 396-402.

Weitzman, S. H. 1962. The osteology of Brycon meeki, a generalized characid fish, with an osteological definition of the family. Stanford Ichthyological Bulletin, 8: 1-77.

Weitzman, S. H. 2003. Subfamily Glandulocaudinae. Pp. 222-230. In: Reis, R. E., S. O. Kullander, C. J. Ferraris Jr. (Eds.). Check list of the freshwater fishes of South and Central America. Porto Alegre, RS, Edipucrs.

Weitzman, S. H. \& W. L. Fink. 1983. Relationships of the neon tetras, a group of South American freshwater fishes (Teleostei, Characidae), with comments on the phylogeny of New World characiforms. Bulletin of the Museum of Comparative Zoology, 150: 339-395.

Weitzman, S. H. \& L. Palmer. 2003. Family Gasteropelecidae. Pp. 101-103. In: Reis, R. E., S. O. Kullander, C. J. Ferraris Jr. (Eds.). Check list of the freshwater fishes of South and Central America. Porto Alegre, RS, Edipucrs. 
Weitzman, S. H. \& R. P. Vari. 1987. Two new species and a new genus of miniature characid fishes (Teleostei: Characiformes) from Northern South America. Proceedings of the Biological Society of Washington, 100: 640-652.

Weitzman, S. H. \& R. P. Vari. 1988. Miniaturization in South American freshwater fishes; an overview and discussion. Proceedings of the Biological Society of Washington, 101: 444-465.

Weitzman, M. \& S. H. Weitzman. 2003. Family Lebiasinidae. Pp. 241-251. In: Reis, R. E., S. O. Kullander, C. J. Ferraris Jr. (Eds.). Check list of the freshwater fishes of South and Central America. Porto Alegre, RS, Edipucrs.

Wiley, E. O. \& G. D. Johnson. 2010. A teleost classification based on monophyletic groups. Pp. 123-182. In: Nelson, J. S.; H.-P. Schultze \& M. V. H. Wilson (Eds.). Origin and phylogenetic interrelationships of teleosts. München Verlag Dr. Friedrich Pfeil.
Zanata, A. M. \& R. P. Vari. 2005. The family Alestidae (Ostariophysi: Characiformes): a phylogenetic analysis of a trans-Atlantic clade. Zoological Journal of the Linnean Society, 145: 1-144.

Zarske, A. 2010. Der Kolibrisalmler - Trochilocharax ornatus gen. et spec. nov. - ein neuer Salmler aus Peru (Teleostei: Characiformes: Characidae). Vertebrate Zoology, 60: 75-98.

Submitted September 30, 2013

Accepted January 20, 2014 by Luiz R. Malabarba

Published June 30, 2014 
Appendix I. List of Miniature Neotropical freshwater fishes, sensu Weitzman \& Vari (1988). Orders are organized in systematic sequence according to Wiley \& Johnson (2010) and within each order taxa are listed in alphabetical order of less inclusive taxa. Classification of families and subfamilies follows Reis et al. (2003) except for the Characidae that follows Mirande (2010) and the use of Eleotridae at the family level (Pezold, 1993). Priocharax is included within the Heterocharacinae according to Mattox \& Toledo-Piza (2012). SL refers to maximum registered standard length in millimeters, except for cases in which total length is given (indicated by an asterisk). References are those that provide largest registered length. Columns numbered 1 to 3 refer to species included in the list by (1) Weitzman \& Vari (1988), (2) Costa \& Le Bail (1999) and (3) present study. "Hyphessobrycon is masculine and it should therefore be Hyphessobrycon albolineatus Fernández-Yépez, 1950 rather than Hyphessobrycon albolineatum Fernández-Yépez, 1950.

\begin{tabular}{|c|c|c|c|c|c|}
\hline Taxon & SL & Reference & 1 & 2 & 3 \\
\hline \multicolumn{6}{|l|}{ CLUPEIFORMES } \\
\hline \multicolumn{6}{|l|}{ Engraulidae } \\
\hline Amazonsprattus scintilla Roberts, 1984 & 19.5 & Weitzman \& Vari, 1988:446 & $\mathrm{X}$ & & \\
\hline Anchoviella manamensis Cervigón, 1982 & 25.0 & Weitzman \& Vari, 1988:446 & $\mathrm{X}$ & & \\
\hline \multicolumn{6}{|l|}{ CHARACIFORMES } \\
\hline \multicolumn{6}{|l|}{ Characidae } \\
\hline \multicolumn{6}{|l|}{ Aphyoditeinae } \\
\hline Axelrodia lindeae Géry, 1973 & 20.6 & Weitzman \& Vari, 1988:446 & $\mathrm{X}$ & & \\
\hline Axelrodia riesei Géry, 1966 & 16.7 & Weitzman \& Vari, 1988:446 & $\mathrm{X}$ & & \\
\hline Axelrodia stigmatias (Fowler, 1913) & 20.5 & Weitzman \& Vari, 1988:446 & $\mathrm{X}$ & & \\
\hline Microschemobrycon elongatus Géry, 1973 & 25.0 & Weitzman \& Vari, 1988:447 & $\mathrm{X}$ & & \\
\hline Microschemobrycon meyburgi Meinken, 1975 & 22.0 & Lima et al., 2003:145 & & & $\mathrm{X}$ \\
\hline Oxybrycon parvulus Géry, 1964 & 15.7 & Weitzman \& Vari, 1988:447 & $\mathrm{X}$ & & \\
\hline Tyttobrycon dorsimaculatus Géry, 1973 & 20.5 & Weitzman \& Vari, 1988:447 & $\mathrm{X}$ & & \\
\hline Tyttobrycon hamatus Géry, 1973 & 16.9 & Weitzman \& Vari, 1988:447 & $\mathrm{X}$ & & \\
\hline Tyttobrycon marajoara Marinho, Bastos \& Menezes, 2013 & 22.1 & Marinho et al., 2013:740 & & & $\mathrm{X}$ \\
\hline Tyttobrycon spinosus Géry, 1973 & 20.5 & Weitzman \& Vari, 1988:447 & $\mathrm{X}$ & & \\
\hline Tyttobrycon xeruini Géry, 1973 & 22.6 & Weitzman \& Vari, 1988:447 & $\mathrm{X}$ & & \\
\hline \multicolumn{6}{|l|}{ Cheirodontinae } \\
\hline Amazonspinther dalmata Bührnheim, Carvalho, Malabarba \& Weitzman, 2008 & 19.6 & Bührnheim et al., 2008:666 & & & $\mathrm{X}$ \\
\hline Cheirodon luelingi Géry, 1964 & 17.6 & Weitzman \& Vari, 1988:446 & $\mathrm{X}$ & & \\
\hline Nanocheirodon insignis (Steindachner, 1880) & 24.4 & Malabarba, 2003:217 & & & $\mathrm{X}$ \\
\hline Odontostilbe gracilis (Géry, 1960) & 23.5 & Malabarba, 2003:218 & & & $\mathrm{X}$ \\
\hline Odontostilbe littoris Géry, 1960 & 18.0 & Malabarba, 2003:218 & & & $\mathrm{X}$ \\
\hline Serrapinnus kriegi (Schindler, 1937) & 23.6 & Malabarba, 2003:219 & & & $\mathrm{X}$ \\
\hline Spintherobolus broccae Myers, 1925 & 25.6 & Malabarba, 2003:220 & $\mathrm{X}$ & & \\
\hline \multicolumn{6}{|l|}{ Heterocharacinae } \\
\hline Priocharax ariel Weitzman \& Vari, 1987 & 17.1 & Weitzman \& Vari, 1988:446 & $\mathrm{X}$ & & \\
\hline Priocharax nanus Toledo-Piza, Mattox \& Britz, 2014 & 15.4 & present paper & & & $\mathrm{X}$ \\
\hline Priocharax pygmaeus Weitzman \& Vari, 1987 & 16.4 & Weitzman \& Vari, 1988:446 & $\mathrm{X}$ & & \\
\hline \multicolumn{6}{|l|}{ Stevardiinae } \\
\hline Creagrutus maracaiboensis (Schultz, 1944) & 22.0 & Lima et al., 2003:124 & & & $\mathrm{X}$ \\
\hline Creagrutus nigrostigmatus Dahl, 1960 & 23.4 & Lima et al., 2003:124 & & & $\mathrm{X}$ \\
\hline Cyanogaster noctivaga Mattox, Britz, Toledo-Piza \& Marinho, 2013 & 17.4 & Mattox et al., 2013:301 & & & $\mathrm{X}$ \\
\hline Iotabrycon praecox Roberts, 1973 & 21.8 & Weitzman \& Vari, 1988:446 & $\mathrm{X}$ & & \\
\hline Pterobrycon landoni Eigenmann, 1913 & 25.1 & Weitzman, 2003:227 & & & $\mathrm{X}$ \\
\hline Scopaeocharax atopodus (Böhlke, 1958) & 22.0 & Weitzman \& Vari, 1988:446 & $\mathrm{X}$ & & \\
\hline Scopaeocharax rhinodus (Böhlke, 1958) & 25.0 & Weitzman \& Vari, 1988:446 & $\mathrm{X}$ & & \\
\hline Trochilocharax ornatus Zarske, 2010 & 17.0 & Zarske, 2010:75 & & & $\mathrm{X}$ \\
\hline Tyttocharax cochui (Ladiges, 1950) & 22.0 & Weitzman \& Vari, 1988:446 & $\mathrm{X}$ & & \\
\hline Tyttocharax madeirae Fowler, 1913 & 17.5 & Weitzman \& Vari, 1988:446 & $\mathrm{X}$ & & \\
\hline Tyttocharax metae Román-Valencia, García-Alzate, Ruiz-C. \& Taphorn, 2012 & 15.8 & Román-Valencia et al., 2012:521 & & & $\mathrm{X}$ \\
\hline Tyttocharax tambopatensis Weitzman \& Ortega, 1995 & 15.5 & Costa \& Le Bail, 1999:1028 & & $\mathrm{X}$ & \\
\hline Xenurobrycon coracoralinae Moreira, 2005 & 15.8 & Moreira, 2005:858 & & & $\mathrm{X}$ \\
\hline Xenurobrycon heterodon Weitzman \& Fink, 1985 & 20.1 & Weitzman \& Vari, 1988:446 & $\mathrm{X}$ & & \\
\hline Xenurobrycon macropus Myers \& Miranda Ribeiro, 1945 & 19.8 & Weitzman \& Vari, 1988:446 & $\mathrm{X}$ & & \\
\hline Xenurobrycon polyancistrus Weitzman, 1987 & 13.8 & Weitzman, 2003:228 & $\mathrm{X}$ & & \\
\hline Xenurobrycon pteropus Weitzman \& Fink, 1985 & 13.8 & Weitzman \& Vari, 1988:446 & $\mathrm{X}$ & & \\
\hline \multicolumn{6}{|l|}{ Tetragonopterinae } \\
\hline Hemigrammus aereus Géry, 1959 & 24.0 & Lima et al., 2003:130 & & & $\mathrm{X}$ \\
\hline Hemigrammus iota Durbin, 1909 & 21.0 & Weitzman \& Vari, 1988:446 & $\mathrm{X}$ & & \\
\hline Hemigrammus luelingi Géry, 1964 & 25.1 & Lima et al., 2003:132 & & & $\mathrm{X}$ \\
\hline Hemigrammus tridens Eigenmann, 1907 & 20.0 & Lima et al., 2003:133 & & & $\mathrm{X}$ \\
\hline Hyphessobrycon albolineatus Fernández-Yépez, 1950 & 25.8 & Lima et al., 2003:134 & & & $\mathrm{X}$ \\
\hline Hyphessobrycon amandae Géry \& Uj, 1986 & 19.5 & Weitzman \& Vari, 1988:446 & $\mathrm{X}$ & & \\
\hline Hyphessobrycon arianae Uj \& Géry, 1989 & 24.0 & Lima et al., 2003:134 & & & $\mathrm{X}$ \\
\hline Hyphessobrycon axelrodi (Travassos, 1959) & 22.0 & Lima et al., 2003:134 & & & $\mathrm{X}$ \\
\hline Hyphessobrycon catableptus (Durbin, 1909) & 18.0 & Weitzman \& Vari, 1988:446 & $\mathrm{X}$ & & \\
\hline Hyphessobrycon ecuadorensis (Eigenmann, 1915) & 20.5 & Lima et al., 2003:135 & & & $\mathrm{X}$ \\
\hline
\end{tabular}




\begin{tabular}{|c|c|c|c|c|c|}
\hline Taxon & SL & Reference & 1 & 2 & 3 \\
\hline Hyphessobrycon griemi Hoedeman, 1957 & 25.7 & Weitzman \& Vari, 1988:447 & $\mathrm{X}$ & & \\
\hline Hyphessobrycon haraldschultzi Travassos, 1960 & 21.0 & Lima et al., 2003:137 & & & $\mathrm{X}$ \\
\hline Hyphessobrycon hildae Fernández-Yépez, 1950 & 18.8 & Lima et al., 2003:137 & & & $\mathrm{X}$ \\
\hline Hyphessobrycon loretoensis Ladiges, 1938 & 24.0 & Weitzman \& Vari, 1988:447 & $\mathrm{X}$ & & \\
\hline Hyphessobrycon minimus Durbin, 1909 & 21.0 & Weitzman \& Vari, 1988:447 & $\mathrm{X}$ & & \\
\hline Hyphessobrycon saizi Géry, 1964 & 23.0 & Lima et al., 2003:140 & & & $\mathrm{X}$ \\
\hline Hyphessobrycon tenuis Géry, 1964 & 26.0 & Lima et al., 2003:141 & & & $\mathrm{X}$ \\
\hline Hyphessobrycon tropis Géry, 1963 & 21.3 & Lima et al., 2003:141 & & & $\mathrm{X}$ \\
\hline Hyphessobrycon tukunai Géry, 1965 & 20.6 & Weitzman \& Vari, 1988:447 & $\mathrm{X}$ & & \\
\hline Paracheirodon innesi (Myers, 1936) & 22.2 & Weitzman \& Vari, 1988:447 & $\mathrm{X}$ & & \\
\hline Paracheirodon simulans (Géry, 1963) & 20.2 & Lima et al., 2003:153 & $\mathrm{X}$ & & \\
\hline \multicolumn{6}{|l|}{ Characidae incertae sedis } \\
\hline \multicolumn{6}{|l|}{ Crenuchidae } \\
\hline Ammocryptocharax minutus Buckup, 1993 & 19.7 & Costa \& Le Bail, 1999:1028 & & $\mathrm{X}$ & \\
\hline Characidium bahiense Almeida, 1971 & 23.3 & Weitzman \& Vari, 1988:447 & $\mathrm{X}$ & & \\
\hline Characidium heinianum Zarske \& Géry, 2001 & 25.0 & Netto-Ferreira et al., 2013a:367 & & & $\mathrm{X}$ \\
\hline Characidium mirim Netto-Ferreira, Birindelli \& Buckup, 2013 & 20.2 & Netto-Ferreira et al., 2013a:363 & & & $\mathrm{X}$ \\
\hline Characidium pteroides Eigenmann, 1909 & 21.1 & Buckup, 2003:90 & & & $\mathrm{X}$ \\
\hline Elachocharax geryi Weitzman \& Kanazawa, 1978 & 19.0 & Buckup, 2003:91 & $\mathrm{X}$ & & \\
\hline Elachocharax junki (Géry, 1971) & 23.1 & Buckup, 2003:92 & $\mathrm{X}$ & & \\
\hline Elachocharax mitopterus Weitzman, 1986 & 13.9 & Weitzman \& Vari, 1988:447 & $\mathrm{X}$ & & \\
\hline Elachocharax pulcher Myers, 1927 & 22.1 & Weitzman \& Vari, 1988:447 & $\mathrm{X}$ & & \\
\hline Klausewitzia ritae Géry, 1965 & 25.0 & Weitzman \& Vari, 1988:447 & $\mathrm{X}$ & & \\
\hline Microcharacidium eleotrioides (Géry, 1960) & 21.0 & Weitzman \& Vari, 1988:447 & $\mathrm{X}$ & & \\
\hline Microcharacidium geryi Zarske, 1997 & 24.0 & Buckup, 2003:88 & & & $\mathrm{X}$ \\
\hline Nannostomus minimus Eigenmann, 1909 & 23.0 & Weitzman \& Cobb, 1975:25 & $\mathrm{X}$ & & \\
\hline \multicolumn{6}{|l|}{ SILURIFORMES } \\
\hline \multicolumn{6}{|l|}{ Aspredinidae } \\
\hline Acanthobunocephalus nicoi Friel, 1995 & 19.7 & Costa \& Le Bail, 1999:1028 & & $\mathrm{X}$ & \\
\hline Hoplomyzon papillatus Stewart, 1985 & 16.9 & Weitzman \& Vari, 1988:448 & $\mathrm{X}$ & & \\
\hline Micromyzon akamai Friel \& Lundberg, 1996 & 15.8 & Costa \& Le Bail, 1999:1028 & & $\mathrm{X}$ & \\
\hline \multicolumn{6}{|l|}{ Astroblepidae } \\
\hline Astroblepus chimborazoi (Fowler, 1915) & 25.0 & Schaefer, 2003:313 & & & $\mathrm{X}$ \\
\hline \multicolumn{6}{|l|}{ Auchenipteridae } \\
\hline Gelanoglanis nanonocticolus Soares-Porto, Walsh, Nico \& Netto, 1999 & 22.2 & Soares-Porto et al., 1999:66 & & & $\mathrm{X}$ \\
\hline Tatia marthae Vari \& Ferraris, 2013 & 23.1 & Vari \& Ferraris, 2013:398 & & & $\mathrm{X}$ \\
\hline \multicolumn{6}{|l|}{ Callichthyidae } \\
\hline Aspidoras brunneus Nijssen \& Isbrücker, 1976 & 21.3 & Weitzman \& Vari, 1988:448 & $\mathrm{X}$ & & \\
\hline Aspidoras carvalhoi Nijssen \& Isbrücker, 1976 & 25.4 & Weitzman \& Vari, 1988:448 & $\mathrm{X}$ & & \\
\hline Corydoras boehlkei Nijssen \& Isbrücker, 1982 & 25.7 & Reis, 2003:295 & & & $\mathrm{X}$ \\
\hline Corydoras cochui Myers \& Weitzman, 1954 & 25.0 & Reis, 2003:296 & & & $\mathrm{X}$ \\
\hline Corydoras gracilis Nijssen \& Isbrücker, 1976 & 23.2 & Weitzman \& Vari, 1988:448 & $\mathrm{X}$ & & \\
\hline Corydoras habrosus Weitzman, 1960 & 20.1 & Weitzman \& Vari, 1988:448 & $\mathrm{X}$ & & \\
\hline Corydoras hastatus Eigenmann \& Eigenmann, 1888 & 24.0 & Reis, 2003:298 & $\mathrm{X}$ & & \\
\hline Corydoras pygmaeus Knaack, 1966 & 23.7 & Weitzman \& Vari, 1988:448 & $\mathrm{X}$ & & \\
\hline \multicolumn{6}{|l|}{ Cetopsidae } \\
\hline Denticetopsis royeroi Ferraris, 1996 & 18.0 & Vari \& Ferraris Jr., 2003:258 & & & $\mathrm{X}$ \\
\hline Denticetopsis sauli Ferraris, 1996 & 21.0 & Vari \& Ferraris Jr., 2003:258 & & & $\mathrm{X}$ \\
\hline \multicolumn{6}{|l|}{ Doradidae } \\
\hline Physopyxis ananas Sousa \& Rapp Py-Daniel, 2005 & 22.0 & Sousa \& Rapp Py-Daniel, 2005:631 & & & $\mathrm{X}$ \\
\hline
\end{tabular}




\begin{tabular}{|c|c|c|c|c|c|}
\hline Taxon & SL & Reference & 1 & 2 & 3 \\
\hline \multicolumn{6}{|l|}{ Heptapteridae } \\
\hline \multicolumn{6}{|l|}{ Loricariidae } \\
\hline Otocinclus tapirape Britto \& Moreira, 2002 & 24.1 & Britto \& Moreira, 2002:1064 & & & $\mathrm{X}$ \\
\hline Parotocinclus amazonensis Garavello, 1977 & 23.0 & $\begin{array}{l}\text { Garavello, } 1988: 125 \text { as } P \text {. } \\
\text { aripuanensis }\end{array}$ & & & $\mathrm{X}$ \\
\hline \multicolumn{6}{|l|}{ Pseudopimelodidae } \\
\hline Microglanis zonatus Eigenmann \& Allen, 1942 & 20.0 & Shibatta, 2003:403 & & & $\mathrm{X}$ \\
\hline \multicolumn{6}{|l|}{ Scoloplacidae } \\
\hline Scoloplax baileyi Rocha, Lazzarotto \& Rapp Py-Daniel, 2012 & 15.4 & Rocha et al., 2012:674 & & & $\mathrm{X}$ \\
\hline Scoloplax baskini Rocha, Oliveira \& Rapp Py-Daniel, 2008 & 16.1 & Rocha et al., 2008:326 & & & $\mathrm{X}$ \\
\hline Scoloplax dicra Bailey \& Baskin, 1976 & 13.8 & Weitzman \& Vari, 1988:448 & $\mathrm{X}$ & & \\
\hline Scoloplax distolothrix Schaefer, Weitzman \& Britski, 1989 & 17.9 & Costa \& Le Bail, 1999:1028 & & $\mathrm{X}$ & \\
\hline Pygidianops сиао Schaefer, Provenzano, de Pinna \& Baskin, 2005 & 18.7 & Schaefer et al., 2005:7 & & & $\mathrm{X}$ \\
\hline Pygidianops eigenmanni Myers, 1944 & 23.0 & Weitzman \& Vari, 1988:447 & $\mathrm{X}$ & & \\
\hline Pygidianops magoi Schaefer, Provenzano, de Pinna \& Baskin, 2005 & 12.6 & Schaefer et al., 2005:7 & & & $\mathrm{X}$ \\
\hline Typhlobelus macromycterus Costa \& Bockmann, 1994 & 21.9 & Costa \& Bockmann, 1994:68 & & & $\mathrm{X}$ \\
\hline Typhlobelus guacamaya Schaefer, Provenzano, de Pinna \& Baskin, 2005 & 22.3 & Schaefer et al., 2005:7 & & & $\mathrm{X}$ \\
\hline \multicolumn{6}{|l|}{ Sarcoglanidinae } \\
\hline Ammoglanis amapaensis Mattos, Costa \& Gama, 2008 & 17.9 & Mattos et al., 2008:162 & & & $\mathrm{X}$ \\
\hline Ammoglanis diaphanus Costa, 1994 & 18.7 & Costa \& Le Bail, 1999:1028 & & $\mathrm{X}$ & \\
\hline Ammoglanis pulex de Pinna \& Winemiller, 2000 & 14.9 & de Pinna \& Wosiacki, 2003:272 & & & $\mathrm{X}$ \\
\hline Malacoglanis gelatinosus Myers \& Weitzman, 1966 & 19.9 & Weitzman \& Vari, 1988:448 & $\mathrm{X}$ & & \\
\hline Microcambeva draco Mattos \& Lima, 2010 & 24.6 & Mattos \& Lima, 2010:236 & & & $\mathrm{X}$ \\
\hline Sarcoglanis simplex Myers \& Weitzman, 1966 & 21.0 & Weitzman \& Vari, 1988:448 & $\mathrm{X}$ & & \\
\hline \multicolumn{6}{|l|}{ Stegophilinae } \\
\hline Tridentopsis cahuali Azpelicueta, 1990 & 22.2 & de Pinna \& Wosiacki, 2003:286 & & & $\mathrm{X}$ \\
\hline Tridentopsis pearsoni Myers, 1925 & 23.0 & Weitzman \& Vari, 1988:448 & $\mathrm{X}$ & & \\
\hline Tridentopsis tocantinsi LaMonte, 1939 & 23.0 & Weitzman \& Vari, 1988:448 & $\mathrm{X}$ & & \\
\hline \multicolumn{6}{|l|}{ CYPRINODONTIFORMES } \\
\hline Poeciliidae & & & & & \\
\hline Poeciliinae & & & & & \\
\hline Cnesterodon raddai Meyer \& Etzel, 2001 & 23.2 & Lucinda, 2003:557 & & & $\mathrm{X}$ \\
\hline Gambusia dominicensis Regan, 1913 & 25.0 & Lucinda, 2003:559 & & & $\mathrm{X}$ \\
\hline Gambusia marshi Minckley \& Craddock, 1962 & 24.0 & Lucinda, 2003:559 & & & $\mathrm{X}$ \\
\hline Gambusia sexradiata Hubbs, 1936 & 26.0 & Lucinda, 2003:559 & & & $\mathrm{X}$ \\
\hline Girardinus cubensis (Eigenmann, 1903) & 26.0 & Lucinda, 2003:561 & & & $\mathrm{X}$ \\
\hline Limia dominicensis (Valenciennes, 1846) & 26.0 & Lucinda, 2003:563 & & & $\mathrm{X}$ \\
\hline Limia garnieri Rivas, 1980 & 26.0 & Lucinda, 2003:563 & & & $\mathrm{X}$ \\
\hline Limia heterandria (Regan, 1913) & 19.5 & Lucinda, 2003:563 & & & $\mathrm{X}$ \\
\hline Limia immaculata Rivas, 1980 & 21.3 & Lucinda, 2003:563 & & & $\mathrm{X}$ \\
\hline Micropoecilia minima (Costa \& Sarraf, 1997) & 23.6 & Costa \& Le Bail, 1999:1028 & & $\mathrm{X}$ & \\
\hline Neoheterandria cana (Meek \& Hildebrand, 1913) & $25^{*}$ & Lucinda, 2003:564 & & & $\mathrm{X}$ \\
\hline Neoheterandria elegans Henn, 1916 & 18.0 & Weitzman \& Vari, 1988:449 & $\mathrm{X}$ & & \\
\hline Neoheterandria tridentiger (Garman, 1895) & $25^{*}$ & Lucinda, 2003:564-565 & & & $\mathrm{X}$ \\
\hline Pamphorichthys araguaiensis Costa, 1991 & 24.5 & Lucinda, 2003:565 & & & $\mathrm{X}$ \\
\hline Pamphorichthys hasemani (Henn, 1916) & 13.8 & Lucinda, 2003:565 & & & $\mathrm{X}$ \\
\hline Pamphorichthys hollandi (Henn, 1916) & 22.4 & Casatti et al., 2006:61 & & & $\mathrm{X}$ \\
\hline Pamphorichthys minor (Garman, 1895) & 15.0 & Weitzman \& Vari, 1988:449 & $\mathrm{X}$ & & \\
\hline Pamphorichthys pertapeh Figueiredo, 2008 & 20.0 & Figueiredo, 2008:62 & & & $\mathrm{X}$ \\
\hline Pamphorichthys scalpridens (Garman, 1895) & 24.8 & Lucinda, 2003:565 & & & $\mathrm{X}$ \\
\hline
\end{tabular}




\begin{tabular}{|c|c|c|c|c|c|}
\hline Taxon & SL & Reference & 1 & 2 & 3 \\
\hline Phallichthys tico Bussing, 1963 & 25.0 & Lucinda, 2003:565 & & & $\mathrm{X}$ \\
\hline Phalloptychus eigenmanni Henn, 1916 & 22.8 & Lucinda, 2005:381 & & & $\mathrm{X}$ \\
\hline Phallotorynus dispilos Lucinda, Rosa \& Reis, 2005 & 25.3 & Lucinda et al., 2005:619 & & & $\mathrm{X}$ \\
\hline Phallotorynus psittakos Lucinda, Rosa \& Reis, 2005 & 25.3 & Lucinda et al., 2005:631 & & & $\mathrm{X}$ \\
\hline Phallotorynus victoriae Oliveros, 1983 & 23.0 & Lucinda et al., 2005:615 & & & $\mathrm{X}$ \\
\hline Poecilia hasemani (Henn, 1916) & 23.0 & Weitzman \& Vari, 1988:449 & $\mathrm{X}$ & & \\
\hline Poecilia parae Eigenmann, 1894 & $20 *$ & Lucinda, 2003:567, as P. amazonica & & & $\mathrm{X}$ \\
\hline Poeciliopsis baenschi Meyer, Radda, Riehl \& Feichtinger, 1986 & 25.0 & Lucinda, 2003:569 & & & $\mathrm{X}$ \\
\hline Priapichthys panamensis Meek \& Hildebrand, 1916 & 25.0 & Lucinda, 2003:572 & & & $\mathrm{X}$ \\
\hline Pseudopoecilia austrocolumbiana Radda, 1987 & 20.0 & Lucinda, 2003:572 & & & $\mathrm{X}$ \\
\hline Quintana atrizona Hubbs, 1934 & 25.0 & Lucinda, 2003:572 & & & $\mathrm{X}$ \\
\hline Scolichthys iota Rosen, 1967 & 25.0 & Lucinda, 2003:572 & & & $\mathrm{X}$ \\
\hline Xiphophorus continens Rauchenberger, Kallmann \& Morizot, 1990 & $25^{*}$ & Lucinda, 2003:573 & & & $\mathrm{X}$ \\
\hline \multicolumn{6}{|l|}{ Protacopodinae } \\
\hline Fluviphylax obscurus Costa, 1996 & 17.3 & Costa \& Le Bail, 1999:1028 & & $\mathrm{X}$ & \\
\hline Fluviphylax palikur Costa \& LeBail, 1999 & 13.9 & Costa \& Le Bail, 1999:1028 & & $\mathrm{X}$ & \\
\hline Fluviphylax pygmaeus (Myers \& Carvalho, 1955) & 22.0 & Weitzman \& Vari, 1988:448 & $\mathrm{X}$ & & \\
\hline Fluviphylax simplex Costa, 1996 & 15.5 & Costa \& Le Bail, 1999:1028 & & $\mathrm{X}$ & \\
\hline Fluviphylax zonatus Costa, 1996 & 15.9 & Costa \& Le Bail, 1999:1028 & & $\mathrm{X}$ & \\
\hline \multicolumn{6}{|l|}{ Rivulidae } \\
\hline Laimosemion jauaperi Costa \& Bragança, 2013 & 18.9 & Costa \& Bragança, 2013:94 & & & $\mathrm{X}$ \\
\hline Laimosemion kirovskyi (Costa, 2004a) & 22.7 & Costa, 2004a: 10 & & & $\mathrm{X}$ \\
\hline Laimosemion romeri (Costa, 2003b) & 21.7 & Costa, 2003b:176 & & & $\mathrm{X}$ \\
\hline Laimosemion uatuman (Costa, 2004b) & 22.2 & Costa, 2004b:3 & & & $\mathrm{X}$ \\
\hline Laimosemion ubim Costa \& Lazzarotto, 2014 & 18.0 & Costa \& Lazzarotto, 2014:371 & & & $\mathrm{X}$ \\
\hline Leptolebias itanhaensis Costa, 2008 & 21.8 & Costa, 2008:152 & & & $\mathrm{X}$ \\
\hline Leptolebias marmoratus (Ladiges, 1934) & 23.3 & Costa, 2002:381 & & & $\mathrm{X}$ \\
\hline Melanorivulus egens (Costa, 2005) & 26.0 & Costa, 2005:80 & & & $\mathrm{X}$ \\
\hline Melanorivulus paracatuensis (Costa, 2003a) & 23.9 & Costa, 2003a:42 & & & $\mathrm{X}$ \\
\hline Melanorivulus rossoi (Costa, 2005) & 21.5 & Costa, 2005:75 & & & $\mathrm{X}$ \\
\hline Melanorivulus rutilicaudus (Costa, 2005) & 22.9 & Costa, 2005:77 & & & $\mathrm{X}$ \\
\hline Notholebias cruzi (Costa, 1988) & 22.9 & Costa \& Le Bail, 1999:1028 & & $\mathrm{X}$ & \\
\hline Notholebias vermiculatus Costa \& Amorim, 2013 & 23.7 & Costa \& Amorim, 2013:68 & & & $\mathrm{X}$ \\
\hline Plesiolebias aruana (Lazara, 1991) & 19.9 & Costa \& Le Bail, 1999:1028 & & $\mathrm{X}$ & \\
\hline Plesiolebias glaucopterus (Costa \& Lacerda, 1989) & 24.1 & Costa \& Le Bail, 1999:1028 & & $\mathrm{X}$ & \\
\hline Plesiolebias lacerdai Costa, 1989 & 19.7 & Costa \& Le Bail, 1999:1028 & & $\mathrm{X}$ & \\
\hline Simpsonichthys cholopteryx Costa, Moreira \& Lima, 2003 & 23.5 & Costa et al., 2003:142 & & & $\mathrm{X}$ \\
\hline Simpsonichthys nigromaculatus Costa, 2007 & 25.6 & Costa, 2007:32 & & & $\mathrm{X}$ \\
\hline Simpsonichthys parallelus Costa, 2000 & 23.5 & Costa et al., 2003:143 & & & $\mathrm{X}$ \\
\hline Spectrolebias costai (Lazara, 1991) & 19.8 & Costa \& Le Bail, 1999:1028 & & $\mathrm{X}$ & \\
\hline Spectrolebias reticulatus (Costa \& Nielsen, 2003) & 20.1 & Costa \& Nielsen, 2003:120 & & & $\mathrm{X}$ \\
\hline Spectrolebias semiocellatus Costa \& Nielsen, 1997 & 22.2 & Costa \& Le Bail, 1999:1028 & & $\mathrm{X}$ & \\
\hline Stenolebias bellus Costa, 1995 & 16.5 & Costa \& Le Bail, 1999:1028 & & $\mathrm{X}$ & \\
\hline Stenolebias damascenoi (Costa, 1991) & 24.4 & Costa \& Le Bail, 1999:1028 & & $\mathrm{X}$ & \\
\hline \multicolumn{6}{|l|}{ GOBIIFORMES } \\
\hline \multicolumn{6}{|l|}{ Eleotridae } \\
\hline Leptophilypnion fittkaui Roberts, 2013 & 9.7 & Roberts, 2013:85 & & & $\mathrm{X}$ \\
\hline Leptophilypnion pusillus Roberts, 2013 & 9.1 & Roberts, 2013:85 & & & $\mathrm{X}$ \\
\hline Microphilypnus acangaquara Caires \& Figueiredo, 2011 & 18.5 & Caires \& Figueiredo, 2011:55 & & & $\mathrm{X}$ \\
\hline Microphilypnus macrostoma Myers, 1927 & 20.0 & Weitzman \& Vari, 1988:449 & $\mathrm{X}$ & & \\
\hline Microphilypnus tapajosensis Caires, 2013 & 22.7 & Caires, 2013:156 & & & $\mathrm{X}$ \\
\hline Microphilypnus ternetzi Myers, 1927 & 23.2 & Caires \& Figueiredo, 2011:49 & $\mathrm{X}$ & & \\
\hline \multicolumn{6}{|l|}{ Gobiidae } \\
\hline Gobiosoma yucatanum Dawson, 1971 & 26.0 & Kullander, 2003b:661 & & & $\mathrm{X}$ \\
\hline \multicolumn{6}{|l|}{ LABRIFORMES } \\
\hline \multicolumn{6}{|l|}{ Cichlidae } \\
\hline Apistogramma juruensis Kullander, 1986 & 24.0 & Kullander, 2003a:614 & & & $\mathrm{X}$ \\
\hline Apistogramma piauiensis Kullander, 1980 & 23.0 & Kullander, 2003a:615 & & & $\mathrm{X}$ \\
\hline Apistogramma staecki Koslowski, 1985 & 21.0 & Kullander, 2003a:615 & & & $\mathrm{X}$ \\
\hline
\end{tabular}


Appendix II. Species originally included in the lists of miniature South American freshwater fishes by Weitzman \& Vari (1988) and Costa \& Le Bail (1999) (in the case of Stauroglanis gouldingi) that either exceed $26 \mathrm{~mm}$ SL or are not currently considered valid species. Orders are organized in systematic sequence following Wiley \& Johnson (2010), and within each order taxa are listed in alphabetical order of less inclusive taxa. Classification of families and subfamilies follows Reis et al. (2003) except for the Characidae that follows Mirande (2010), and the use of Eleotridae at the family level (Pezold, 1993).

\begin{tabular}{|c|c|c|}
\hline Taxon & Justification & Reference \\
\hline \multicolumn{3}{|l|}{ Tetragonopterinae } \\
\hline Hyphessobrycon diancistrus Weitzman, 1977 & Maximum SL: $30 \mathrm{~mm}$ & Lima et al., 2003:135 \\
\hline Hyphessobrycon georgettae Géry, 1961 & Maximum SL: $32 \mathrm{~mm}$ & Lima et al., 2003:136 \\
\hline Hyphessobrycon megalopterus (Eigenmann, 1915) [cited as & Maximum SL: $36.4 \mathrm{~mm}$ & Lima et al., 2003:138 \\
\hline \multicolumn{3}{|l|}{ Megalamphodus rogoague by Weitzman \& Vari (1988)] } \\
\hline Nannostomus marginatus Eigenmann, 1909 & Maximum SL: $35 \mathrm{~mm}$ & Weitzman \& Weitzman, 2003:245 \\
\hline \multicolumn{3}{|l|}{ SILURIFORMES } \\
\hline \multicolumn{3}{|l|}{ Aspredinidae } \\
\hline Dupouyichthys sapito Schultz, 1944 & Maximum SL: $30 \mathrm{~mm}$ & Friel, 2003:263 \\
\hline \multicolumn{3}{|l|}{ Callichthyidae } \\
\hline Aspidoras pauciradiatus Weitzman \& Nijssen, 1970 & Maximum SL: $29 \mathrm{~mm}$ & Reis, 2003:292 \\
\hline Trichomycteridae & & \\
\hline \multicolumn{3}{|l|}{ Sarcoglanidinae } \\
\hline Stauroglanis gouldingi de Pinna, 1989 & Maximum SL: $27 \mathrm{~mm}$ & de Pinna \& Wosiacki, 2003:278 \\
\hline \multicolumn{3}{|l|}{ Tridentinae } \\
\hline Tridensimilis brevis (Eigenmann \& Eigenmann, 1889) & Maximum SL: $30 \mathrm{~mm}$ & de Pinna \& Wosiacki, 2003:286 \\
\hline \multicolumn{3}{|l|}{ Vandeliinae } \\
\hline Paravandellia bertonii Eigenmann, 1918 & $\begin{array}{l}\text { Synonym of Paravandellia oxyptera } \\
\quad \text { Miranda Ribeiro, } 1912\end{array}$ & de Pinna \& Wosiacki, 2003:277 \\
\hline Paravandellia oxyptera Miranda Ribeiro, 1912 & Maximum SL: $28 \mathrm{~mm}$ & de Pinna \& Wosiacki, 2003:277 \\
\hline $\begin{array}{l}\text { Paravandellia phaneronema (Miles, 1943) [cited as Paravandellia } \\
\text { magdalenae by Weitzman \& Vari (1988)] }\end{array}$ & Maximum SL: $28 \mathrm{~mm}$ & de Pinna \& Wosiacki, 2003:277 \\
\hline \multicolumn{3}{|l|}{ CYPRINODONTIFORMES } \\
\hline
\end{tabular}

